\title{
Kuka teki Suvisoiton? Säveltäjä ja muusikko musiikkiteoksen tuottajina
}

Itsestäänselvyydeltä tuntuva ajatus säveltäjästä musiikkiteoksen tekijänä syntyi länsimaisen taidemusiikkikulttuurin piirissä vasta romantiikan aikana. Yhä edelleen monissa musiikkiteoksen ontologiaa käsittelevissä teksteissä (kts. esim. Levinson 1990/1980; Goodman 1981/1968 ja Wolterstorff 1980) teoksen merkitys redusoidaan säveltäjään ${ }^{1}$. Tällainen käsitys musiikkiteoksesta säveltäjän itseilmaisun tuotteena ei vastannut omia kokemuksiani huilistina teoksen olemisen tavoista. Toisenlaisen käsityksen esiinnostamiseksi aloin tutkia sitä, miten yksi musiikkiteos - Usko Meriläisen Suvisoitto huilulle ja heinäsirkoille (1979) - käsitteellistetään säveltäjä Usko Meriläisen ja Suvisoiton kantaesittäjän, huilisti Mikael Helasvuon puheessa. Tämä aineisto koostuu Meriläisen ja Helasvuon haastatteluista sekä niistä dokumentoiduista huilutunneista, joilla olen Helasvuon oppilaana opiskellut Suvisoittoa. Kiinnostukseni kohteena tässä artikkelissa on säveltäjän ja muusikon välinen valtasuhde. Musiikkiteosta voidaan tarkastella mistä tahansa paikasta, jossa sitä esitetään lausuntoja. Käsittelen tässä teosta sellaisena kuin se ilmenee muusikon ja säveltäjän puheessa.

Analysoin Meriläisen ja Helasvuon puhetta diskurssin käsitteen avulla. Michel Foucault'n mukaan $(1991,49)$ diskurssit ovat käytäntöjä, jotka systemaattisesti muodostavat niitä objekteja, joista ne puhuvat. Tämän ajatuksen mukaisesti en tarkastele kielen käyttöä siltana todellisuuteen, vaan osana todellisuutta itseään (kts. Jokinen, Juhila ja Suoninen 1993). Lähtökohtanani on ajatus, että musiikkiteos määritellään kielen avulla, jolloin kielen ja sen kohteen välinen ero asetetaan kyseenalaiseksi.

Diskurssin voidaan nähdä muodostuvan elementtien (käsitteiden, ilmiöiden, asioiden) välisistä merkityssuhteista: "Elementtien väliset merkitykselliset sidokset syntyvät sosiaalisissa käytännöissä. Tätä merkityksellistämisen prosessia kutsutaan artikulaatioksi ja elementtien välille rakentunutta verkostoa diskurssiksi." (Jokinen ja Juhila 1991, 15.) Artikulaation avulla kytketään toisiinsa elementtejä, jotka eivät välttämättä aiemmin ole olleet kytköksissä toisiinsa (kts. Grossberg 1995, 268).

\footnotetext{
${ }^{1}$ Näiden taideteorioiden ongelmista enemmän kts. Leppänen 1996.
} 
Länsimaisen taidemusiikkikulttuurin kenttä jaetaan luovaan ja esittävään säveltaiteeseen: luovalla säveltaiteella viitataan säveltämiseen ja esittävällä säveltaiteella soittamiseen. Suomen kielen perussanakirja (1992) määrittelee luovan sellaiseksi, joka 'käyttää henkisiä kykyjään tieteelliseen t. taiteelliseen työhön, luomiskykyinen; em. alueella jtak uutta tuottava". Luoda-verbin merkityksiä ovat muun muassa seuraavat: "tuottaa (tyhjästä) jtak, aiheuttaa jnk olemassaolo", sekä "tuottaa, saada aikaan, keksiä jtak uutta tieteellisen t. taiteellisen toiminnan avulla". Esittää-verbin merkityksiksi kirja tarjoaa muun muassa seuraavaa: "esiintyä, vars. tulkita taideteosta muiden nähden t. kuullen: lausua, soittaa, näytellä tms.". Esittävä-sanaa ei sanakirjassa esiinny ollenkaan. Näiden määrittelyjen perusteella on selvää, kenellä on valtaa ja millainen toiminta on arvokasta. Luovuuden tuotos - tässä tapauksessa sävellys - on jotain uutta kun taas esittäjä reprodusoi, tulkitsee jo valmista taideteosta. Luovuus ja esittävyys muodostavat dikotomisen käsiteparin siinä mielessä, että luovuuden ajatellaan oleva ei-esittävää ja esittävyyden ajatellaan olevan ei-luovaa. Luovan säveltaiteen diskurssin hegemonisen aseman vuoksi länsimaisen taidemusiikin tutkimus on keskittynyt säveltäjien ja teosten tutkimiseen. Pyrin tässä artikkelissa purkamaan luovan ja esittävän säveltaiteen dikotomiaa lähtökohtanani se ajatus, että luovaan toimintaan sisältyy aina myös esittäviä ulottuvuuksia ja päinvastoin (kts. Lehtonen 1994, 103).

Käytän Meriläisen ja Helasvuon puheen analysoimiseen kahta elementtiä, joita he käyttävät tehdessään ymmärrettäväksi musiikkiteoksen olemusta ja sen toimintatapoja. Näiden elementtien identifioimisen jäljille minut johdattelivat seuraavat Meriläisen lausumat:

Kyllä minä aika tarkkaan ${ }^{2}$ pyrin merkitsemään miten soitetaan, täs on nyt ihan tarpeeks huilulla vapautta (III: 7) 3 .

- - se on asianyhteys joka minusta on ihanteellinen et minä voin koko ajan tietää mitä minä haluan mutta kuitenkin siinä [soittamisessa] on tietty vapaus ja esittäjän oma persoona saa tulla esille (I: 8).

Näiden tekstikohtien jännite kuvaa kahden merkitysmaailman välistä ristipainetta: Miten on mahdollista, että säveltäjä yhtä aikaa voi hallita esitystä ja kuitenkin antaa muusikolle vapauden? Käsitteellistääkö myös muusikko samat asiat tarkoiksi ja vapaiksi kun säveltäjä vai ei? Vapauden ja tarkkuuden teemat

\footnotetext{
2 Tunti- ja haastatteluaineiston litterointien tekstikorostukset (kursivoinnit ja lihavoinnit) eivät viittaa Meriläisen ja Helasvuon puhumisen tapaan, vaan aineiston analyysin kannalta tärkeisiin tekstikohtiin.

${ }^{3}$ Litteraatioviitteissä roomalaiset numerot viittaavat nauhan numeroon ja arabialaiset numerot viittaavat litteraation sivunumeroon.
} 
ovat läsnä koko Suvisoittoa koskevassa tutkimusaineistossa sekä säveltäjän että muusikon puheessa. Yhtäältä he puhuvat sellaisista asioista, jotka ovat tarkkoja, säännöllisiä tai hallittuja. Toisaalta taas kielen käytössä toistuvat sellaiset teoksen kuvaukset, joissa painotetaan vapautta, tulkinnanvapautta, valintaa, aleatorisuutta ja improvisaatiota.

Analysoin tässä artikkelissa näiden kahden elementin käyttöä eli sitä, miten muusikko ja säveltäjä käsitteellistävät Suvisoiton käyttämällä tarkkuuden ja vapauden käsitteitä. Käsittelen aineistoa parametreittain siksi, että Meriläinen ja Helasvuo kohdentavat lausumansa Suvisoitosta puhuessaan yleensä yhteen parametriin kerrallaan.

\section{Dynamiikka}

Meriläinen ja Helasvuo puhuvat haastattelu- ja tuntiaineistossa dynamiikasta erittäin vähän. Helasvuo mainitsee ainoastaan yhdellä huilutunnilla suoranaisesti dynamiikan (II: 15). Luullakseni suurin syy siihen, miksi dynamiikkamainintoja on tuntiaineistossa näin vähän, on se, että en ehtinyt $\mathrm{Su}$ visoiton opiskelussa niin pitkälle, että olisi ollut syytä puuttua dynaamisiin asioihin. Tällainen työskentelytapa eli se, että dynamiikka on jotain joka 'lisätään' soittoon, kertoo osaltaan paljon musiikkiteoksen käsitteellistämisen tavoista.

Helasvuo käyttää dynamiikan metaforana sanaa adjektiivi (IV: 8), joka mielestäni kuvaa dynamiikan lisäämistä johonkin jo olemassaolevaan asiaan. Hän sanookin, että säveltäjät yleensä lisäävät dynamiikan kuvittelemaansa esitykseen. Adjektiivihan määrittää itsensä ulkopuolisen ilmiön olemisen tapaa. Lento-osan hiljaisesta dynamiikasta puhuessaan Helasvuo sanoo, että piano-nyanssi on "hyvin yleinen määrä" (IV: 6). Piano-merkintä ei siis määritä kovin tarkasti sitä nyanssia, jolla pitäisi soittaa. Samanlaista epämääräisyyttä luonnehtii Meriläinen todetessaan, että ensimmäisen sivun lopussa oleva mezzoforte-merkintä ei tarkoita välttämättä sitä, että nyanssi siitä eteenpäin olisi mezzoforte vaan että se on pikemminkin vihje siitä, että "nyt ollaan sillä alueella" (III: 3).

Meriläisen mukaan musiikkia yleensä ja sävellysprosessin kuulomielikuvia voi yrittää kuvata vastakohtaparien avulla. Hän nimeää seuraavat sanaparit: kova ja pehmeä, heleä ja tumma, voimakas ja hiljainen sekä liike ja pysähtyminen. (III: 4.) Tässä sanapari voimakas ja hiljainen viittaa tietysti dynamiikkaan, mutta huomattavaa on se, että Meriläinen puhuu nimenomaan musiikin kuuntelemisesta ja kuulomielikuvista. Tuotetaanko dynamiikka ehkä siis vahvasti esityksellisenä eikä niinkään nuottikuvallisena parametrina? Dynamiikan asemaa Suvisoitossa selvittää seuraava haastattelukatkelma: 
T. L.: - - onks mahdollista erotella sellasii asioita että mitkä seikat esityksessä sitten määräytyy nuottikuvan mukaan ja mitkä ei?

U. M.: Kaikki määräytyy nuottikuvan mukaan. Siis tällasia dynamiikkavaihtelua ehkä joku soittaa rajummin voimakkaammin - -. (I: 9.)

Dynamiikan kannalta oleellista edellisessä sitaatissa on se, että Meriläinen mainitsee nuottikuvan kaikenmääräävyyden jälkeen nimenomaan dynamiikan. Näin hän siirtyy mahdollisimman kauaksi nuottikuvallisuudesta ja niistä ilmiöistä, joiden ajatellaan olevan tarkasti sidoksissa siihen. Hän vihjaa, että dynamiikka on jotakin sellaista, jonka ei ajatella sijaitsevan nuottikuvassa samassa määrin kuin joidenkin muiden parametrien. Dynamiikka kuuluu suurelta osin esityksen ja esittämisen kategorioihin, joskin nuottikuva saattaa antaa dynamiikkaa koskevia "adjektiivinomaisia" vihjeitä. Nämä vihjeet muodostavat Suvisoiton dynamiikan nuottikuvallisen rungon eli ne asiat, jotka sijoitetaan ensisijaisesti nuottikuvaan.

Miten säveltäjä pystyy perustelemaan sen, että nuottikuvan ei tarvitse kokonaan määritellä dynamiikkaa, jos kuitenkin 'kaikki" asiat esityksessä määräytyvät nuottikuvan mukaan? Meriläinen sanoo, että nauha ja akustiikka ${ }^{4}$ määrittävät dynamiikkaa. Dynamiikka ei siis sekään synny kokonaan ilman säveltäjän kontrollia, onhan hän tehnyt nauhan joka osaltaan kontrolloi dynaamista tapahtumista. Akustiikka on nauhan lisäksi dynamiikkaa määrittävä ei-nuottikuvallinen ehto. Dynaamista vapautta rajoittavat siis sekä nuottikuvalliset että ei-nuottikuvalliset seikat.

Helasvuon mielestä Suvisoiton notaatiossa on miellyttävää se, että se ei ole ylikuormitettu dynamiikalla,

koska esitys tuo tullessaan märätyn dynamiikan aina kuitenkin ja usein se dynamiikka on semmonen, jonka säveltäjä sitten myöskin lisää kuvittelemaansa esitykseen jollei oo sitten loppujen lopuks muuta merkitystä. Säveltäjät ei aina oo suinkaan mitään hyviä esittäjiä. Ne ehkä kuvittelee sen esityksen ja laittaa niinku peittää sen semmosen moskan alle et se on hyvä jos se on mahdollisimman kirkas, ettei oo liikaa niinku runo on kirkas ja hyvä jos siin ei oo hirveesti niitä adjektiiveja. (IV: 8.)

\footnotetext{
${ }^{4}$ Tämä voi kuulostaa itsestäänselvyydeltä ja sitä se varmasti onkin: jokainen muusikko tietää, että akustiikka vaikuttaa muun muassa juuri dynaamisiin ratkaisuihin. Tämän tutkimuksen kannalta on tärkeää päästä kuitenkin juuri näiden itsestäänselvyyksien taakse ja tarkastella sitä, miten nämä itsestäänselvyydet tuotetaan ja minkälaisia seurauksia niillä on. Eihän olisi mahdotonta kuvitella, että länsimainen taidemusiikkikulttuuri olisi muotoutunut esimerkiksi sellaiseksi, että sävelkorkeus ajateltaisiin tilannekohtaiseksi, vaikkapa akustiikasta riippuvaiseksi parametriksi.
} 
Helasvuon tuskin voisi kuvitella edellä olevan katkelman tavoin puhuvan muista parametreista - esimerkiksi siitä, että nuottikuva olisi ylikuormitettu säveltasoilla tai rytmillä. Muiden parametrien kohdalla ei myöskään olisi tarpeellista viitata esityksellisyyteen eli siihen, että säveltäjän pitäisi olla hyvä esittäjä voidakseen ilmaista niitä nuottikuvalla. Säveltasoja ja rytmiä ei myöskään ajatella lisättävän kuviteltuun esitykseen ${ }^{5}$. Säveltäjän ja muusikon välillä vallitsee yhteisymmärrys siitä, että dynamiikka on ehdottomasti pikemminkin esityksellinen kuin nuottikuvallinen parametri.

Helasvuo jakaa dynamiikan tuottamiseen kahteen osaan: siihen, jonka muusikko ehkä kirjoittaa nuottiinsa ja siihen, jonka esitys tuo "väkisinkin" tullessaan. Eri esityskerroilla dynaamiset painotukset eivät hänen mielestään voi tapahtua aivan samalla tavalla. (IV: 8.) Dynamiikka on siis ainakin osittain häilyvää ja epäpysyvää. Musiikkiteoksen tai sen jonkin osan dynamiikka voi olla häilyvää ja muuttuvaa ilman että teosta kokonaisuudessaan tai sen osaa luonnehdittaisiin improvisatoriseksi.

\section{Sointiväri}

Meriläinen käyttää monenlaisia sanoja kuvatessaan Suvisoiton nauhan sointiväriä: hän puhuu "kuivasta sirinästä", "ihmeellisistä sävyistä", "heleydestä", "kirkkaudesta", "huilumaisuudesta", "jännittävästä naksutuksesta", "raksuttavasta aineksesta", "pisaroista", "helmeilevyydestä", "huilumaisesta helmirivistä", "ratisevasta äänestä", "tiheästä säkätyksestä" ja "nakuttavasta linjasta" (I: 2, I: 4, III: 5, III: 6, III: 9). Suvisoiton huiluosuuden kuvauksissa tämäntyyppiset luonnehdinnat puuttuvat lähes kokonaan. Meriläinen määrittelee huiluosuuden sointivärin varsin erilaisin käsittein: hän puhuu lähinnä huilun uusista soittotavoista, jotka merkitsevät tämän soittimen "väriaineksen lisääntymistä".

T. L.: Tää [Suvisoitto] aloitti sen huilukauden niin mikä huilussa kiehtoi?

U. M.: Nimenomaisesti se tavaton soinnillinen rikkaus mikä mikä huilussa on ja - - sanoisin tässä nykykäytännöissä jollon tämmönen multifoniamaailma ja mikrointervallit ja glissandot ja kaikki mahdollinen on tullu käsiin ja erilaiset soittotavat flageolettiäänet ja tämmöset whistletonet ja kiss ja kaikki kielitekniikka ja sehän on tavattoman hieno soitin, - - josta on nyt viime vuosina niinkun kaikilla puhaltimilla puupuhaltimilla erityisesti niin on löytyny tavattomasti käyttökelposia ja mitä moninaisimpia soittotapoja, jotka merkitsee sitten tämän soittimen sanosinko väritysaineksen tai väriaineksen lisääntymistä tavattomasti ja minä todella innostuin huiluun. (I: 10.)

${ }^{5}$ Dynamiikkaa ei siis lisätä ainoastaan esitykseen, vaan muusikon käsityksen mukaan myös säveltäjä lisää sen muuten jo valmiina olevaan nuottikuvaan. 
Ne Meriläisen kuvaukset, jotka koskevat nimenomaisesti Suvisoiton huiluosuuden sointiväriä, tapahtuvat edellisen sitaatin kaltaisten soittoteknisten termien avulla. Näitä nimityksiä ovat flatterzunget, multifoniat, mikrointervallit ja poco suono -äänen tuottaminen. Nämä kuvaukset poikkeavat varsin paljon siitä edellä kuvatusta tavasta, jolla Meriläinen puhuu nauhan sointiväristä.

Ei ainoastaan sointiväriä koskevat kuvaukset vaan myös sointiväriin liittyvä verbisanasto on varsin erilainen riippuen siitä, puhuuko Meriläinen Suvisoiton nauhasta vai huiluosuudesta. Nauhan sointiväriä kuvaillessaan hän käyttää teonsanoja, jotka korostavat hänen omaa tekemistään ja hallintaansa nauhan suhteen:

- - siellä Ylen studiossa niin mua rupes kiinnostamaan se aines, joka oli semmosta naksutusta ja minä suodatin sitä vähän ja panin kovan kaiun siihen ja sitten siitä tuli semmonen helmeilevä ja minä tein sen näin ihan käsillä ja että se lähti hitaasti ja nopeammin ja hidastui. Joo ja monet luulee että se on huilulta otettu, mutta ei kyllä se on jollakin tavalla suodattamalla ja - - kaiun kautta saanut ulos tämmösen erittäin huilumaisen helmirivin sieltä. (III: 5.)

Tällaisia säveltämisen kuvauksia - sointivärin suoranaisen tekemisen ja muokkaamisen prosessin kuvauksia - on melkein yksinomaan nauhan osuutta koskevassa haastatteluaineistossa.

Meriläinen siis tekee ja muokkaa aktiivisesti nauhan sointiväriä, mutta huiluosuuden sointivärin tuottamisessa muusikko on tärkeässä asemassa. On tietysti selvää, että muusikko ei voikaan muuttaa nauhaa. Kiinnostavaa tässä onkin, miksi Meriläisen säveltäminen ei ulotu huiluosuuden sointiväriin asti ${ }^{6}$. Nauhahan on tavallaan Meriläisen tekemä esitys toisin kuin nuottikuva, huilun osuus. Sointiväri on edellisten huiluosuutta koskevien lausumien perusteella suuressa määrin muusikon tehtävä, esityksellinen parametri.

Meriläinen sanoo oppineensa Helasvuolta "tavattoman paljon" (I: 5). Kysyessäni häneltä, mitä se tarkoittaa, hän mainitsee ensimmäisenä oppineensa Helasvuolta nimenomaan "huilun tavattoman soinnillisen rikkauden" (III: 15). Sointiväri on siis jotain sellaista, jota muusikko voi opettaa säveltäjälle. Sointivärillisiä mahdollisuuksia lisäävät huilun uudet soittotavat käsitteellistetään niin suuressa määrin muusikon tehtäviksi, että säveltäjä voi niiden käytössä pyytää muusikkoa avukseen. Helasvuo antoi Meriläiselle "paljon eväitä olemalla vaan hyvä huilisti" (III: 16). On tärkeää huomata, että Meriläinen mainitsee hyvän kontaktin muusikkoon tärkeäksi juuri sointiväriparametrin kohdalla ja tuottaa näin sointivärin vahvasti esityksellisenä parametrina.

\footnotetext{
${ }^{6}$ Meriläinen toteaa venäläisen huilistin esittämästä Suvisoitosta, että "äänellisesti hän - sai tavattomasti kyllä irti tästä (III: 12)". Tämän perusteella sointivärillä voidaan siis ajatella olevan myös lievän nuottikuvallisiakin ulottuvuuksia esityksellisten ulottuvuuksien painokkuudesta huolimatta.
} 
Dynamiikkaa käsittelevässä luvussa kerroin siitä, että Meriläisen mukaan musiikkia yleensä ja sävellysprosessiin liittyviä mielikuvia voi yrittää kuvata vastakohtaparien avulla. Hän nimesi seuraavat vastakohtaparit: kova ja pehmeä, heleä ja tumma, voimakas ja hiljainen sekä liike ja pysähtyminen. (III: 4.) Tässä kyse on nimenomaan musiikin kuuntelemisesta ja kuulomielikuvista. Mielenkiintoista tässä on se, miten sointivärilliseksi Meriläinen näissä molemmissa kohdissa musiikin kuuntelemisen - esityksen - ja mielikuvat määrittelee. Näin hän määrittelee myös sointivärin vahvasti esitykselliseksi parametriksi.

Myös Helasvuo tuottaa sointivärin ensisijaisesti esitykselliseksi parametriksi. Tuntitilanteissa hän viittaa sointiväriin liittyvään valinnanvapauteen toteamalla, että sointivärin valinta on "up to your taste" (II: 1), sen voi teknisesti suorittaa monella tavalla ja siinä täytyy käyttää omaa keksintää (II: 8). Nämä lausumat koskevat siis asioita, joissa Helasvuo ei halua sanella yhtä tapaa, jolla hän haluaisi, että ne tehdään.

Kaikkia sointiväriin liittyviä asioita ei kuitenkaan käsitteellistetä tässä aineistossa vapaina. Helasvuo kuvailee seuraavasti sitä sointivärillistä tulkintatraditiota, johon katsoo Suvisoiton kuuluvan:

Tässä tyylissähän on se ideahan on se imitaatio sen nauhan kanssa mitä siel tapahtuu, eikä niinkään se klassinen kirkas [sointiväri]. Ei sun tarvitse tunnontarkasti koko ajan pitää huolta siit äänestä, sun pitää pitää huolta niist reaktioista ja ajasta siit äänen muuttumisesta ja siitä eloisuudesta, mikä siinä äänessä on, ettei se oo parhaimman kuulosta sillai jos se soi kirkkaasti niinku joku tommonen Andersenin etydi koko ajan.

Tässä on varsin tarkasti määritelty se tulkintatraditio, johon Helasvuo ajattelee Suvisoiton sointivärillisesti kuuluvan. Dynamiikkaa koskevista tulkintatraditioista Meriläinen ja Helasvuo eivät puhu mitään, joten kokonaisuudessaan sointivärin voidaan ajatella olevan siis jollakin tavalla enemmän tulkintatraditiosidonnainen ilmiö kuin dynamiikan. Tulkintatraditiot ennaltamääräävät ja rajoittavat sointivärin vapautta.

Sointivärin vapauden ja tarkkuuden elementit kietoutuvat toisiinsa myös Meriläisen puheessa:

T. L.: Onks kaikki sellaset soinnilliset asiat jotka on sillon mielessä kun säveltää jotain teosta niin pyritäänkö ne yleensä kirjottamaan ylös vai jätetäänkö niitä aika paljon merkitsemättä?

U. M.: Kyllä minä aika tarkkaan pyrin merkitsemään miten soitetaan, täs on nyt ihan tarpeeks huilulla vapautta. (III: 6-7.)

Yhtäältä on siis olemassa sellaisia sointivärillisiä ilmiöitä, jotka säveltäjä merkitsee nuottikuvaan. Nämä ilmiöt pyritään merkitsemään nuottikuvaan tarkasti ja säveltäjällä on syytä olettaa, että muusikko tulkitsee niitä kohtuullisessa määrin siten kuin säveltäjä haluaa. Toisaalta on kuitenkin olemassa sellaisia 
sointivärillisiä ilmiöitä, joista nuottikuva ei sano mitään tai jotka kuuluvat osittain vapauden elementin piiriin. Vaikka nämä ilmiöt erotetaan kielenkäytössä toisistaan, niin ne voivat silti esiintyä yhdessä ja samassa esityksen hetkessä. Nuottikuvan ajatellaan esimerkiksi määrittelevän suhteellisen tarkasti mikrointervallin sävelkorkeuden muttei välttämättä sen sointiväriä ${ }^{7}$.

Tämän artikkelin säveltaso-organisaatiota käsittelevässä luvussa saamme huomata, että säveltaso-organisaation referentti on kaksitoistasävelinen silloinkin kun se itse asiassa poikkeaa siitä. Sointivärin kohdalla samantyyppinen ilmiö on se, että Meriläinen luonnehtii flatterzunge-soittotapaa "ei-puhtaaksi huiluksi", "murtuneeksi ja puhisevaksi ääneksi" sekä tavallisen soittotavan soinnilliseksi vastakohdaksi (III: 4, 11). Poco suono -ääni puolestaan ei ole "vielä kirkas" ja se on "suhiseva" ja "kuiskaava" (III: 1). Multifonista ääntä hän luonnehtii siten, että yksi ääni murtuu sävelkentiksi (III: 1) ja että se on soinnillinen vastakohta tavanomaiselle äänenmuodostukselle (III: 11). Uudempien soittotapojen referentti on siis tavanomainen, pidempiperinteinen äänenmuodostus. Tätä seikkaa ei kuitenkaan korosteta tässä aineistossa yhtä paljon kuin säveltaso-organisaation kaksitoistasävelisyyttä ${ }^{8}$. Tähän ei ilmeisesti ole syytä siksi, että sointiväri on esityksellisempi parametri kuin säveltaso-organisaatio. On kuitenkin oireellista, että Meriläinen mainitsee ei-puhtaaksi, ei-kirkkaaksi, "murtuneeksi" ja "puhisevaksi" juuri sellaisen äänen, johon tutustumisessa hän on tarvinnut muusikon apua vastakohtana "puhdistuneelle oikealle äänelle" ja "selvälle avautuneelle huilusoinnille" (III: 1-2). ${ }^{9}$ Näillä hän tarkoittaa tavanomaista tapaa muodostaa ääni.

Meriläinen korostaa huilun ja nauhan sointivärien vastakohtaisuutta suhteessa toisiinsa: nauha on vastakohta "huilun kirkkaalle ainekselle" (III: 14). Helasvuo puolestaan puhuu huilun homogeenisesta sulautumisesta nauhan maailmaan ja "motivoitumisesta siinä" (IV: 6). Näin sanoessaan hän ilmeisesti puhuu yleisesti kaikista parametreista. Toisaalla hän sanoo lento-osassa yrittävänsä tuottaa sellaista sointiväriä, joka "toimisi" nauhan sointivärin kanssa. Tämä tapahtuu Helasvuon mukaan kahdella tavalla: toisaalta on kysymys "imitoinnista" ja toisaalta "kontrastoimisesta" tai "kontrapunktoimisesta"

7 Mikrointervallin nuottikuvallisen sävelkorkeuden ajatellaan tarkoittavan tavallaan yhtä äänenkorkeutta, jolla tosin on rajat, joiden sisään sen pitää mahtua ollakseen hyväksyttävä. Mikrointervallin sointiväri puolestaan voi olla monta, eikä mahdollisia sointivärejä ajatella jatkumona vaan selkeästi erillisinä ilmiöinä.

8 Tästä enemmän säveltaso-organisaatiota käsittelevässä luvussa.

${ }^{9}$ Samaa asiaa heijastaa myös Helasvuon ironinen kommentti: "Sittehän tulee - - tää seuraava kuvio: et puolestavälistä rivii tulee poco suono, vivacissimo poco a poco suono [?]. Se tarkottaa sitä mitä siinä sanotaan, että vähitellen ääntä enemmän ja enemmän ensin soitetaan suttusella äänellä ensin soitetaan normaalilla äänellä ja sitten soitetaan mestarisäänellä. " (IV: 2.) 
(IV: 10). Mistä johtuu se, että säveltäjä painottaa enemmän nauhan ja huiluosuuden sointivärillistä vastakohtaisuutta, kun taas muusikko korostaa sitä, että huilun sointivärin pitäisi toimia nauhan sointivärin kanssa? Vastaus löytyy taas sointivärin vahvasti esityksellisestä luonteesta, siitä, että sointiväri tuotetaan enemmän esityksellisenä kuin nuottikuvallisena parametrina:

- - yritä kuunnella niitä saundeja mitä sä kuulet siinä kohdassa [lento-jaksossa]. Et se ei riitä, jos sä soitat miten vaan, vaan yrität kuunnella, et saisit tehdä dialogin. Se on ihan susta kiinni, et se ei oo vaan suoritus, vaan kuuntelet niitä pienii värijuttuja mitä siellä on. (II: 15.)

Sointiväri on muusikolle erittäin tärkeä parametri siksi, ettei esitys jää pelkäksi "suoritukseksi". On siis olemassa esitys, joka on pelkkä suoritus ja toisaalta jotain muuta. Tämä muu tuotetaan tässä tapauksessa ainakin sointivärin avulla. Sointiväri - kuten myös dynamiikka - siis tavallaan lisätään esitykseen. Sointivärin on esityksen tasolla oltava "dialogissa" ja "toimittava" nauhan kanssa koko ajan. Niinpä muusikolle on mahdollista - toisin kuin säveltäjälle - se, että hänen mielestään sekä "imitoiminen" että "kontrapunktoiminen" ovat sointivärin "toimimisen" alaluokkia.

Meriläinen kuvailee koko haastatteluaineistossa ainoastaan kahta Suvisoiton esitystä. Toinen näistä tapahtui Moskovassa sävellysliiton järjestämässä Meriläisen sävellyskonsertissa. Säveltäjä sanoo olleensa ihastunut tähän esitykseen siksi, että se oli soinnillisesti niin hyvä ja kaunis. Meriläinen kertoo, että huilisti sai äänellisesti tavattoman paljon irti Suvisoitosta. (III: 12.) Hän sanoo ylipäätään esityksissä kiinnittävänsä huomiota siihen, miten selkeää soitto on ja millaista se on äänellisesti. Nämä ovat hänen mielestään tärkeimmät asiat sen lisäksi, että soitetaan oikein. (III: 14.) Sointiväri on siis niin tärkeä esityksellinen parametri, että jos se toimii esityksessä hyvin, niin säveltäjä voi sallia nuottikuvallisten ilmiöiden tai parametrien - tässä tapauksessa rytmin - toteuttamisen toisin kuin hän olisi halunnut.

\section{Ajan organisaatio}

70-luvulta asti Meriläinen sanoo halunneensa yhdistää teoksissaan säännöllisen ja epäsäännöllisen rytmin (I: 3). Myös Helasvuo sanoo, että vapaan ja rytmillisen rytmikudoksen rinnakkaisuus on nykymusiikin eräs tärkeimmistä jännitteenluomiskeinoista siksi, että nykymusiikista puuttuvat perinteisessä merkityksessä tonaaliset jännitteet. (IV: 4.) Mitkä oikeastaan ovat näiden kahden rytmikudostyypin sisällöt? Meriläisen ja Helasvuon lausumista löytyy seuraavia nimityksiä näille ilmiöille: pulssi ja ei-pulssi, tarkkuus ja vapaus, epäsäännöllisyys ja säännöllisyys, selkeys ja rytmisyys. Ilmausten suhde nuottikuvaan on selvä: säännöllisellä rytmillä viitataan äänitapahtumiin, jotka ovat traditio- 
naalisesti palkein ja varsin varustetuin nuotein notatoituja (I: 3). Säännöttömällä rytmillä viitataan niihin äänitapahtumiin, joissa ajan organisointi ei tapahdu traditionaalisen hierarkkisesti. Yksinkertaisimmillaan on siis kyse siitä, ajatellaanko jonkin teoksen kohdan olevan pulsatiivinen vai ei.

Ilmiö näyttäytyy paljon monimutkaisempana, jos lähdetään tarkastelemaan seuraavia kysymyksiä: Mikä tämä ero on ja miten se tuotetaan? Mistä nämä rytmikudostyypit ovat vapaita ja millä tavalla ne ovat tarkkoja? Miksi juuri pulssittomuus käsitteellistetään vapaudeksi?

\section{Säännötön rytmi}

Meriläinen korostaa säännöttömään pulssiin liittyvää soittajan vapautta. Tällaisen rytmikudoksen ominaisuudeksi hän nimeää luonnollisuuden: "mä uskon, että se tulee sitten lopulta luonnostaan kun [muusikon] ei tarvitse laskee eikä saa laskea eikä voi laskea mitään". Meriläisen tarkoituksena ei-pulssillisissa kohdissa on "herättää soittajan omia mielikuvia". (III: 2.) Luonnollisuuden lisäksi houkutetaan esille "soittajan aivan kuin sisäinen rytmitaju ja sisäinen kyky" sijoittaa tiettyyn aikaan tietyt asiat. Meriläinen tulee tässä sijoittaneeksi vapauden pois itsestään ja omasta kontrollistaan: luonnollisuuteen ja muusikkoon. Tämä vapaus edustaa siis selvästi esityksellisyyttä. Meriläisen mielestä on hämmästyttävää ja merkillistä, että näin tosiaan tapahtuu; muusikko osaa jäsentää oikean tempon Suvisoitossa siten, että huiluosuudet sijoittuvat nuottikuvan mukaisesti oikein nauhaimpulssien väleihin. (III: 7.) Hän sanoo antavansa soittajille tietyn vapauden siten, ettei pakota rytmiä tarkaksi. Tällöin soittajien ei tarvitse "laskea tahtia ja jännittää jotain rytmiä vaan ne saavat soittaa sen vapaasti". (I: 8.)

Miksi säveltäjä painottaa näin voimakkaasti sitä, että säännötön pulssi edustaa vapautta? Myöhemmin tässä luvussa tulen käsittelemään samaa asiaa muusikon lausumissa, joista käsin tarkasteltuna säveltäjän kuvaukset näyttävät liioitelluilta. Säveltäjällä on tietysti kuitenkin syynsä määritellä tämä vapaus edellä kuvatulla tavalla. Sanapari säännöllinen/säännötön ilmaisee, että jälkimmäisestä sanasta puuttuu se sääntö, joka edellisessä on. Pulssi/ei-pulssi -käsiteparista voidaan päätellä - kuten edellä jo totesin - että tämä sääntö on pulssi. Vapaus puolestaan on vapautta pulssista ja tarkkuus usein tarkkuutta pulssin suhteen. Pulssillisuudesta poikkeavat ilmiöt käsitteellistetään siis negaation kautta; pulssin puuttumisena, ei-pulssina. Meriläinen tuottaa traditionaalisen, pulssihierarkkisen notaation normaalina: hän sanoo osoittavansa nuottikuvassa ne paikat, joissa pyritään rytmiseen tarkkuuteen, "normaalilla" notaatiolla ja metronominumerolla (I: 7). Meriläinen sanoo, että hänelle on luontaista se, että "on tietty rytmi mutta sitä ei kahlita mihinkään säännölliseen pulssiin" (I: 6). Kahlita-verbin avulla hän kuvailee pulssillisen rytmikudoksen erittäin tarkaksi verrattuna ei-pulssilliseen rytmikudokseen. Tämän mukaan pulssi aiheuttaa 
ajan organisaatiolle enemmän reunaehtoja kuin ei-pulssi, säännöllinen rytmi kahlitsee ajallista tapahtumista enemmän kuin säännötön. Pulssi on tässä aineistossa niin keskeinen tapa jäsentää Suvisoiton aikaa, että se on ajan jaksottumisessa läsnä ei-pulssina silloinkin, kun sitä ei rytmikudoksessa ajatellakaan olevan.

Ajan organisaatio - rytmi - on ilmiö, jonka ajatellaan olevan nuottikuvassa joka hetkellä määrätty: Meriläinen sanoo, että 60-luvun aleatorisuudessa mentiin hyvinkin pitkälle, kun annettiin esittäjän valita jopa sävelkorkeudet ja rytmin osalta käytettiin varsin "epämääräisiä vihjeitä". Tässä on kysymys negatiivisesta vapaudesta, jota on liikaa. Meriläinen haluaa tietää joka hetki, mitä tapahtuu ja että asiat ovat hänen hallinnassaan. Ääriesimerkkinä hallitsemattomuudesta hän mainitsee Kyma-jousikvartetossa olevan improvisaatiojakson, jossa hän antaa kullekin soittajalle muutaman sävelen. Näitä säveliä käyttäen soitetaan improvisaatio, jolta Meriläinen edellyttää, että rytmi rakennetaan edellisten motiivien perusteella tai niitä käyttäen. (I: 8.) Säveltäjän nuottikuvaan ennaltamääräämä rytmi on siis äärimmäisessä improvisatorisessa hallitsemattomuudessakin aina läsnä.

Tätä taustaa vasten on helppo ymmärtää, miksi rytmiä koskeva vapaus täytyy sijoittaa selvästi muusikkoon ja esitykseen eikä säveltäjään ja nuottikuvaan. Syy tähän on ensinnäkin se, että säveltäjä haluaa pitää tämän parametrin kontrollissaan sillä tavalla, että ajan organisaatiota koskevassa vapaudessa painottuvat sen esitykselliset ulottuvuudet nuottikuvallisten kustannuksella. Ajan organisaatio tuotetaan niin tärkeäksi ja nuottikuvalliseksi parametriksi, että sitä koskeva vapaus ei ole yhtä mahdollista kuin dynamiikkaa ja sointiväriä koskeva vapaus. Toisena syynä on ajan organisaation pulssillinen referentti, joka on niin vahva, että sen puuttuessa ajan organisaation painopiste siirretään säveltäjästä ja nuottikuvasta muusikolle ja esitykseen. Ei-pulssillinen, säännötönkin rytmi pysyy säveltäjän hallinnassa siten, että hän korostaa itse antavansa ja haluavansa antaa tämän vapauden muusikolle (I: 8; III: 7; III: 8). Säveltäjä määrää, missä ja miten rytmiä koskeva vapauskin toimii.

\section{Nauha}

Meriläinen kuvailee huilun ja nauhan keskinäistä suhdetta niissä kohdissa, joissa huiluosuus on ei-pulssillista, painottaen vapautta: vapaa liike on "ad libitum siinä mielessä, että soittaja lukee tätä topografikarttaa tässä ja sijottaa ne [huiluosuudet] vähän mielen mukaan [...] niihin väleihin." (I: 3.) "Mielenmukaisuus" rajoittuu kuitenkin ainoastaan nauhaimpulssien väleihin, jotka tosin ovat pidempiä Suvisoiton ei-pulssillisissa kuin pulssillisissa jaksoissa. Tällöin "mielenmukaisuus" kestää tietysti ei-pulssillisissa jaksoissa kerrallaan pitemmän aikaa kuin pulssillisissa kohdissa. Nauha asettaa tästä huolimatta erittäin tarkat 
ajalliset rajat niille säännöttömänkin rytmin jaksoille, jotka sijoittuvat nauhan referenssipisteiden välille.

Suvisoiton nuottikuvan alussa Meriläinen sanoo panneensa "vapaat hahmot" suorakaiteen sisään:

- - näiden pisaroiden paikat on määritelty suurinpiirtein, ei mitenkään sekunnintarkkaan eikä - - tämä kartta - - ole sillä tavalla rytmisesti määritelty vaan - ne ovat tämmösenä hiukan summittaisena graafisena kuvana ilmaistu. (I: 4.)

On totta, että pisaroiden paikkaa ei ole sekunnintarkkaan määritelty nuottikuvassa jos ajatellaan äänten paperilla viemän tilan suhdetta niiden kestoon. Nauha kuitenkin määrittää näidenkin pisaroiden paikat paljon tarkemmin kuin mitä nuottikuva tarkimmillaankaan pystyisi tekemään.

Muusikko ei tuota säännötöntä rytmiä läheskään yhtä voimakkaasti vapauden elementin kautta kuin säveltäjä. Helasvuo neuvoo minua harjoittelemaan nauhan kanssa: "Koita nyt sen [nauhan] kanssa ni sit sä saat siitä ideaa, huomaat tippuvas pois aika pian, mut sit ku siihen tottuu [...] siinä tulee niitä maamerkkejä (II: 11)." Suuri osa Suvisoiton harjoitteluprosessista liittyy juuri siihen, että huilisti saa muun muassa ajallisen yhtäaikaisuuden nauhan kanssa toimimaan. Ääninauhan osuushan pysyy aina rytmisesti samanlaisena. Tästä johtuen muusikon ja ääninauhan yhtäaikaisuudessa on kyse täysin eri asiasta kuin jos esittäjinä olisi kaksi soittajaa. Synkronisuhde on siis Suvisoitossa yksisuuntainen, kaikki vastuu yhtäaikaisuudesta jää huilistille. Tätä prosessia helpottaakseen Helasvuo merkitsee sellaisissa kohdissa, joissa on säännötön pulssi, nuottikuvaan tarkempia ajan jaksotuspisteitä kuin mitä siinä itsessään valmiina on:

Mä itte teen sillä tavalla, että mä tämmösessä oppiakseni sen ajotuksen niin mä tota sekuntoin sen usein sillai, et mä - - suurinpiirtein sillai ryhmittelen niin sit sä et rupee niinku ex tempore syöksymään sinne ja arvioimaan et jotain tällasta se oli. Siin pitää olla joku sisäinen pulssijako - - ni se auttaa sit usein yllättävän hyvin. - - ihminen oppii sillä tavalla myös sen ajatuksen - - . Kuuskymment - - menee helposti, tommonen yhden sekunnin mittanen rytmi, jon$\mathrm{ka}--$ heitto on aika pieni ja itsellä se on usein aika sama. (IV: 3.)

Helasvuo siis merkitsee nuottikuvaan viivoja noin sekunnin välein helpottaakseen yhdessä nauhan kanssa soittamista. Säveltäjän kuvailema säännöttömän rytmin vapaus saa osakseen aivan toisenlaisen näkökulman: soittamisen ja esityksen tasolla vapaus on liian vapaata siksi, että synkronin nauhan kanssa täytyy toimia melko tarkasti. Siksi muusikko muuttaa nuottikuvassa olevan vapauden melko tarkaksi, oppiakseen muistamaan tapahtumisen nopeuden. Vaikka säännötön rytmi käsitteellistetäänkin usein vapaaksi ja säännöllinen tarkaksi 
niin säännötön rytmi on vapaampi kuin säännöllinen vain ja ainoastaan pulssin suhteen.

Silloin, kun Meriläinen ei puhu erityisesti nimeten säännöttömästä rytmistä, hän näkee nauhan ja huilun synkronin erittäin tarkkana:

Itse asiassa siis sanoisin, että tämä on klassisempi teos kun Chopinin masurkka siinä mielessä, että nauha on niin arka. Se menee se tulee se ääni sieltä just sillon ja se on soitettava ne äänet siihen väliin - - . Tämä on soitettava tarkemmin kun - - Chopinin masurkka, täss ei oo ollenkaan semmosia vapauksia, vaan nauha on armoton partneri. (I: 10.)

Mitä tarkoitusta tarkkuus tässä palvelee? Meriläinen ja Helasvuo puhuvat yllättävän usein siitä, että Suvisoiton nuottikuva ei jossakin kohdassa vastaa heidän mielestään sitä, miten se pitäisi soittaa. Meriläinen sanoo, että kolmannen sivun ensimmäisen rivin rytmiset suhteet ovat aivan väärät: Nuottien saama tila paperilla ei tila-aikanotaation tyyppisesti vastaa niiden kestoa ajassa.



Kuva 1. Suvisoitto, $3 / 1^{10}$

Ensimmäinen nuotti on merkitty kuudeskymmenesneljäsosaksi, joten kuvion pitäisi olla erittäin nopea. Meriläinen sanoo tarvinneensa nopeuden takia pieneen tilaan paljon nuotteja ja etumerkkejä, jolloin ne eivät sijaitse niin lähekkäin toisiaan kuin niiden suhteessa kestoon pitäisi. Meriläinen sanoo, että vaikka hänen sävellyksissään tällaisissa kohdissa yleensä onkin olemassa rytminen suhde - vastaavuus nuottien saaman tilan paperilla ja niiden esityksellisen keston välillä - niin se ei ole ehdoton. Suvisoitossa tällainen näennäinen epäehdottomuus muuttuu osittain vastakohdakseen nauhan olemassaolon takia. Nauha kontrolloi ja ennaltamäärää parametreista ehdottomimmin ja tarkimmin juuri ajan organisaatiota. Tässä kohdassa nuottikuvaan merkityt, huilun äänitapahtumaa reunustavat nauhaimpulssit määrittävät tapahtuman keston ja sen myötä äänten kestot hyvinkin tarkasti.

${ }^{10}$ Merkintä 3/1 tarkoittaa Suvisoiton nuottikuvan kolmannen sivun ensimmäistä riviä. 
Tällaiset epäjohdonmukaisuudet nuottikuvassa ovat mahdollisia nimenomaan nauhan olemassaolon vuoksi. Nauhalla on Suvisoitossa monia nuottikuvallisia tehtäviä: monissa kohdissa se määrää varsinkin esityksen ajallista tapahtumista tarkemmin kuin nuottikuva. Näiden nuottikuvallisten funktioiden vuoksi myös säveltäjän kontrolli esitykseen - onhan hän nauhan tekijä - on joillakin tasoilla huomattavasti suurempi kuin sellaisissa esityksissä, jotka tapahtuvat pelkän nuottikuvan perusteella. Nauhahan määrittää ei ainoastaan esityksen kokonaiskestoa vaan myös jaksotuspisteiden välisen tapahtumisen ajan esityksestä toiseen aina samanpituiseksi.

\section{Lento ja presto}

Ehdoton ajallisen organisaation tarkkuus löytyy presto-jaksoa koskevista lausumista. Meriläinen sanoo, että nopean lopun rytmi on tarkka (I: 4). Hän nimittää prestoa myös finaaliksi, jossa on "rytminen meno" ja jonka täytyy olla rytmisesti yhtäaikainen nauhan kanssa. Prestossa muusikon ei ole mahdollista poiketa nauhan rytmistä, vaan hän "on hukassa jos putoo kelkasta". (III: 11.) Helasvuon mielestä presto-jakso on ahdistava, epämiellyttävä ja ärsyttävä siksi, että se on niin nopea ja vaikea soittaa yhdessä nauhan kanssa (II: 6, 11). Nauha on Helasvuon mukaan myös epärytminen, ja vaikka nauha olisi rytmissäkin, niin jakso olisi vaikea soittaa (II: 6; IV: 5). Ilmeisesti tämän takia Helasvuon mielestä huilun ja nauhan yhtäaikaisuus on vain periaatteellinen (II: 6). Hän ei ajattele yhteissoittoa yhtä tarkaksi kuin säveltäjä:

Se on tota se on älyttömän ikävä soittaa yhdessä. Se ei oo ihan hirveen rytminenkään - - ja se sisältö nyt siitä niin kauheen pienistä asioista kiinni oo, mut jos toi rytmi ois hyvä niin se ois tietysti ideaali. (II: 6.)

Miten säveltäjän ja muusikon käsitykset huilun ja nauhan rytmisen yhtäaikaisuuden tarkkuudesta presto-jaksossa voivat poiketa näin huomattavassa määrin toisistaan? Puhuvatko he ehkä kokonaan eri asioista? Presto-jakson tarkkuus on paradoksaalinen. Säveltäjä puhuu tässä yhteydessä - kuten hyvin usein tässä aineistossa - tarkkuudesta paljolti pulssin synonyymina. Kun tapahtumien nopeus on kuitenkin niin suuri kuin tässä jaksossa, niin ehdotonta pulssin luomaa ajan jaksotuspisteiden samanaikaisuutta huilun ja nauhan kesken on melko mahdotonta saavuttaa. Toisaalta tapahtumien nopeus on myöskin niin suuri, että tarkkuuden illuusion luominen kuulijalle ei vaadi esitykseltä yhtäläistä tarkkuutta kuin nuottikuva näyttäisi edellyttävän. Tästä johtuen muusikon käsitys "periaatteellisesta" nauhan ja huilun yhtäaikaisuudesta ehkä riittää täyttämään säveltäjän vaatiman ehdottoman tarkkuuden ehdot. Säveltäjän ja muusikon lausumissa on kyse kahden erilaisen Suvisoiton tuottamisesta. Säveltäjä voi puhua ainoastaan nuottikuvasta tai siitä, miltä esityksen pitäisi hä- 
nen mielestään kuulostaa. Muusikko taas puhuu soittamisen tapahtumasta, esityksen toteuttamisesta.

Säveltäjä mainitsee - kuten jo edellä kerroin - koko haastatteluaineistossa ainoastaan kaksi Suvisoiton esitystä. Molempia esityksiä käsitellessään hän puhuu eniten juuri preston soittamiseen liittyneistä vaikeuksista ja virheistä. Venäläinen huilisti Moskovassa sanoi Meriläiselle jo ennen esitystä, ettei hän pysty seuraamaan nauhaa presto-kohdassa, ja Pierre-Yves Artaud myöhästyi Viitasaarella preston "lähdöstä" (III: 12). Meriläinenhän käsitteellistää preston hyvin voimakkaasti tarkkuuden elementin kautta (I: 4). Tässä voisi olla syy siihen, miksi hän esityksen virheistä puhuessaan puhuu aina juuri prestosta. Tarkkuus on vahvasti nuottikuvallinen ilmiö ja säveltäjä ajatellaan nuottikuvan tekijäksi jolloin tarkkuuden toteuttaminen on säveltäjälle tietysti tärkeää. On mielenkiintoista, että Meriläinen antaa periksi ehdottoman tarkkuuden vaatimuksistaan edellä mainituissa tapauksissa eli puhuessaan tietyistä esityksistä. Ei siis ainoastaan esityksistä vaan nimenomaan tietyistä esityksistä. Hän sanoo venäläisen huilistin esityksestä: 'Minä saatoin ihan hyvin hyväksyä sen että se ei ollu tarkka." Myöskin Artaudin esityksestä hän sanoo, että epäonnistuminen ei häntä itseään - toisin kuin Meriläisen sanojen mukaan Artaudia - haitannut kovin paljon. (III: 12-13.) Säveltäjä siis käsitteellistää Suvisoittoa tarkkuuden elementin kautta puhuessaan teoksesta yleisesti ja nimenomaan sen nuottikuvasta, mutta tämä tarkkuus sietää melko paljon poikkeamia yksittäisten esitysten tasolla. "Virheet" voi siis antaa anteeksi, jos esityksellä on muita ansioita.

Helasvuo sanoo, että prestossa huilistilla ei juurikaan ole vaihtoehtoja tulkinnallisissa ratkaisuissa. Joitakin ääniä voi korostaa, ottaa esille ja tehdä artikulaatioaksentointeja. Aksentoinnit ja ryhmittämisetkin ovat hänen mielestään tässä yhteydessä saivartelua nopean tempon takia. (IV: 6.) Hän käsitteellistää tarkkuutta ja vapautta käsiteparilla osaaminen/tulkitseminen:

- - seuraava jakso [presto] niin soitettas parhaiten jos olis absoluuttinen huilukone, se ois niinku absoluuttisesti toivottavin esitys. Esimerkiks - - siin on erittäin vähän tulkitsemiselle siin on osaamiselle paljon tilaa mut tulkinnallisille ratkaisuille siin ei ole tilaa - - . Tietysti pieniä asioita: minkätyyppisen staccaton mut se on niin nopea että käytännössä - - se on todella vaikee soittaa. Sit ku se ei viel oo ihan täysin rytmissä se nauha, vaikka se ois rytmissä niin silti se on vaikee jakso tää. (IV: 5 .)

"Osaaminen" on nuottikuvallisten asioiden toteuttamista ja tarkkuutta kun taas "tulkitseminen" koskee niitä asioita, joista nuottikuvan ajatellaan vaikenevan ja antavan näin tilaa vapaudelle. Tulkinnalliset ratkaisut vaativat siis tilaa, jota prestossa on hyvin niukasti. Lento-jaksossa tilaa on runsaasti. Meriläisen kuvaus lentosta on tällainen: 
T. L.: Sit tulee tää siirtyminen tähän hitaampaan jaksoon ennen tota loppurytistystä?

U. M.: Joo, siinä on tämmönen minun symbolini on vähän no kyllä ne riittävän selviä ovat. Siinähän tapahtuu tämmönen siin on tuo helminauha ja tämmönen säkätys joka on hyvin tiheä ja sitten se taso laskee ja tulee semmonen nakuttava linja joka menee näin ja siinä on sitten taas soittajalla tilaisuus antaa sen soittaa hidastusta täällä niinkun tahtoo ja sittenhän sinne jää ihan yksin nämä ja nyt on kysymys siitä - - millon tulee tuohon d säveleeseen. Siinä odottaa kunnes kuulee sitten tän pling äänen sieltä jokka oli hyvin hiljasia ääniä joita minä sain vahvistettua ja ja puhdistettua sitten [?] pois ja vielä hiljaisempi oli tämä. Mä olin oikein iloinen, että mä sain ne pelastettua siellä jotenkin ne mikä on tuon fis plim-äänen jälkeen. Se on semmonen hyvin hiljanen pieni liike. Se on merkillistä, että siellä se vaan oli ja mä sain kaivettua esiin tän. Tää hidas jaksohan tässä on erittäin yksinkertainen. Siinä on nauha-aines se - - koostuu ihan näistä kahdesta ominaisuudesta. (III: 9.)

Tässä katkelmassa - joka on ainoa paikka koko aineistossa, jossa Meriläinen käsittelee lentoa - on mielenkiintoista se, että Meriläinen puhuu melkein yksinomaan nauhan osuudesta. Ainoastaan kursivoimani lausumat koskevat huilun osuutta. Näissä molemmissa lausumissa Meriläinen puhuu muusikon vapaudesta, tulkinnan vaihtoehtojen valikoimasta ja muusikon omien ratkaisujen mahdollisuudesta.

Meriläinen puhuu paljon prestosta ja tuottaa sen ensisijaisesti, kuten edellä kuvasin, tarkkuuden elementin kautta. Helasvuon kuvaukset prestosta rajoittuvat melko lakonisiin toteamuksiin sen soittamisen vaikeuksista:

M. H.: Joo ja sit alkaa toi kiva.

T. L.: Emmä pysty tätä.

M. H.: Mut siin ei oo mitään sen kummempaa, se on vaan se on ihan motorinen ja se on ihan rytmissä. Soitas tosta. (II: 14.)

Soittokehotus katkelman lopussa viittaa nuottikuvan seitsemännelle sivulle eli muualle kuin presto-jaksoon. Helasvuo ohittaa tai ylittää preston tässä tilanteessa kokonaan viitaten sen yksinkertaisuuteen suhteessa valinnanvapauteen. Tunnilla ei siis ole tästä syystä ole tarpeen kuluttaa aikaa sen läpikäymiseen. Lento-jaksoa koskevissa kuvauksissa tilanne on täsmälleen päinvastainen: Meriläinen puhuu lentosta lyhyesti keskittyen nauhaosuuteen ja niukkoihin mainintoihin muusikon vapaudesta sekä jakson yksinkertaisuudesta, kun taas Helasvuo kertoo lentosta laveasti painottaen muusikon laajaa valinnanvapautta tässä etenkin juuri ajan organisaatioon liittyen. Hän sanoo, että tämä "jakso on hyvin paljon esittäjästä kiinni, esittäjän - - hahmottamishalusta ja - - se saattaa muuttaa hahmoaan aika paljon riippuen siitä kuinka se esitetään" (IV: 6). Ajoittamisratkaisuja lento-jaksossa Helasvuo kuvailee seuraavasti: 
M. H.: - - siis se on ihan siis vaan jänniteasia, tulkinnan asia et koska mä lähden toiselle rivillä liikkeelle sit ku tulee gis ja koska se flähtee. Mä ajattelen et siinä on pieni rako, mutta minkälainen se on, ne on kaikki niitä ratkasuja, jotka liittyy ihan siihen kuinka sen tulkitsee.

T. L.: Voiko sitä mitenkään perustella että miten sen ratkasun tekee tai että miten se vaikuttaa siihen jännitteeseen että miten pitkä se väli on sen gissän ja äffän välillä?

M. H.: No se on sen voi niinku tehdä kahella tavalla: siihen voi tehdä pienen sesuuran, sen voi myös tehdä jatkumona. Se on valintakysymys - - . (IV: 6.)

Muusikko ja säveltäjä tuottavat siis presto- ja lento-jaksot melko eri tavalla. Näitä jaksoja koskevan aineiston perusteella näyttää siltä, että tarkkuuden elementti tuottaa ensisijaisesti säveltäjän tehtävät ja vapauden elementti muusikon tehtävät. Tätä kautta tarkkuus liittyy ensisijaisesti nuottikuvaan ja vapaus esitykseen. Tämän vuoksi säveltäjällä on enemmän sanottavaa tarkaksi tuottamastaan prestosta ja muusikolla runsaasti tulkintatilaa tarjoavasta lentosta.

Tarkkuuden ja vapauden elementit liittyvät myös siihen, miten nopeaksi musiikin tapahtuminen ajatellaan: kun Helasvuo sanoo, että prestossa on paljon tilaa osaamiselle mutta vähän tulkitsemiselle, on kysymys myös aivan konkreettisesta tilasta. Prestossa nuottikuvan määräämä tapahtumien nopeus ajatellaan niin suureksi, että muusikolla ei ole tilaa tehdä enää mitään muuta nuottikuvan ennaltamääräämien asioiden toteuttamisen lisäksi. Nopeissa jaksoissa kuten prestossa muusikko ajatellaan levyautomaatin kaltaiseksi koneeksi, johon syötetään nuottikuva sisään ja joka reprodusoi nuottikuvan ennaltamääräämät tapahtumat mahdollisimman tarkasti ehtimättä lisäämään siihen mitään. Lenton tapahtumien tiheys taas käsitteellistetään niin hitaaksi, että muusikolla on tilaa ja aikaa tehdä muutakin kuin toteuttaa nuottikuvan määräämiä musiikillisia tapahtumia.

Helasvuo nimeää lento-jakson staattiseksi vedoten säveltäjäkohtaiseen tulkintatraditioon; Meriläisen teosten hitaat osat ovat hänen mukaansa yleensä juuri staattisia:

T. L.: Mitä sellaseen staattiseen soittoon kuuluu?

M. H.: No sitä tietysti että - - heiluu vähemmän ja - - ääni pysyy jollain tavalla. Pitkii äänii, sehän luo jo sellasenaan staattisuutta. Pitkii äänii, se on niinku tapahtumaköyhää. Vibraato purkaa sitä staattisuutta, niin sillon vähentää varmaankin vibraatoa, ja eleet on niinku hitaampia. - Meriläisen tollaset hitaat osat on yleensä staattisia, niinku aika pysähtyy niissä yleensäkin Meriläisen teoksissa, joita tässä yhteydessä kannattaa varmaan enemmänkin tota kuunnella. (IV: 10.)

Se että Helasvuo kuvaa lentoa tapahtumaköyhäksi, on ristiriidassa sen kanssa, että hän aiemmin sanoi jakson riippuvan hyvin paljon muusikon hahmotta- 
mishalusta. Tulkinnallisten ratkaisujen tasolla muusikko on ilmeisesti siis hyvin kiireinen tässä jaksossa. Ristiriita selittyy sillä, että hän todennäköisesti viittaa nuottikuvalliseen ja nauhan tapahtumaköyhyyteen. Tämä tapahtumaköyhyys antaa tilaa muusikon tulkinnan vapaudelle. Vapaus ja tulkinnanvapaus ajatellaan siis jollakin tasolla lisäyksinä nuottikuvaan. Helasvuo sanoo esimerkiksi, että hän haluaisi antaa lento-jaksolle mielen (IV: 6). Silloin kun nuottikuvassa ajatellaan olevan tilaa, näitä lisäyksiä on mahdollista tehdä.

\section{Rytmi ja agogiikka}

Meriläinen kertoo havainnollistaneensa rytmiä ja agogiikkaa luennollaan Tampereen yliopistolla soittamalla pianolla Chopinin masurkkaa sillä tavalla kuin se on kirjoitettu. Tämä oli vaikeaa siksi, että hänellä oli suuri viehtymys tehdä agogiikkaa. Hän sanoo joutuneensa keskittymään siihen, että soitti masurkan aivan "tarkkaan". Tämän jälkeen hän kuuntelutti saman masurkan puolalaisen pianistin "herkullisesti" soittamana levytyksenä. Äänitteessä yksikään tahti ei ollut samanlainen vaan nuottiarvot olivat "koko ajan pidempiä, pitempiä, lyhyempiä". (I: 9-10.) Rytmi on siis Meriläisen käsitejärjestelmässä nuottikuvallinen ilmiö, ajan organisaatio siten kuin se on nuottikuvaan kirjoitettu. Agogiikka puolestaan on esityksellinen parametri, jonka muusikko lisää nuottikuvaan. Tarkkuuden elementti tuottaa säveltäjän tehtävän, rytmin, ja vapauden elementti tuottaa muusikon tehtävän, agogiikan.

Helasvuo on valinnut Suvisoiton kolmannen sivun toiselta riviltä (in the tempo of the tape -merkinnästä) alkavan ja sivulle neljä toisen rivin puolitaukoon päättyvän jakson karakteriksi scherzandon:

Scherzando tarkottaa sitä niinku leikkisää osastoa. Joka on leikkisä, ei oo koskaan hirveen rigoröösi vaan leikkisä [...] vähän - - ottaa tommosia omavaltaisuuksia, pilailee niinku vakavilla asioilla. - - Mä oon ajatellu tän niinku vähän sillai capriccioso, joka tuntuu tuovan jatkuvasti mukanaan rytmillisiä vapauksia enemmän kun mitä nuottikuva suoranaisesti - - antaa tilaa . (IV: 9.)

Leikkisien karakterien, jotka Helasvuo nimeää scherzandoksi ja capricciosoksi, seurauksena muusikon on mahdollisuus ottaa omavaltaisuuksia, vapauksia, suhteessa vakaviin ja tarkkoihin asioihin. Tarkkuuden elementin kautta tuotetut vakavat asiat rinnastuvat tässä rytmiin ja vapauden elementin kautta tuotetut omavaltaisuudet agogisiin seikkoihin. Tarkka nuottikuva ei suoranaisesti anna tilaa näille vapauksille, mutta agogiikan vapauden avulla ja vapauden elementin tuottamien leikkisien karakterien avulla nämä ovat mahdollisia loukkaamatta kuitenkaan liikaa nuottikuvan "vakavuutta". Helasvuo puhuu tässä yhteydessä nimenomaan tottelemattomuudesta: leikkisä ei hänen mukaansa ole 
tottelevainen (IV: 9). Leikkisyyden avulla mahdollistuu vapauden ottaminen suhteessa ankaraan nuottikuvaan.

Leikkisyys on siis vapauden elementin tuottama esityksellinen karakteri. Tarkkuuden elementti puolestaan tuottaa vakavan karakterin. Helasvuo sanoo, että neljännen sivun toisella rivillä puolitauon jälkeen - jossa nauhalla alkaa "ankarampi, jykevämpi ja hitaampi pulssi" - tapahtuu leikkisyyden vakavoituminen. Nauhan tempon jähmettyminen pakottaa tähän vakavoitumiseen:

T. L.: $\quad-\quad$ mikä tässä pakottaa sellaseen niinku tavallaan...

M. H.: No se on vaan se, että tavallaan nuottikuva, et - - tohon rupee tulemaan tarkkaa, toi palkki aina määrättyihin aikoihin, ja se on motivina vähän semmonen ankara: ku[i]n ruohonleikkuukoneen virittämistä heinäsirkalle; vakavoittaa hetkeksi sirkan mielen. (IV: 9.)

Vakavoituminen - tarkkuus - tapahtuu siis tässäkin ensinnäkin nauhan nuottikuvallisen funktion seurauksena ja toiseksi nuottikuvalliseksi kuvailtujen ilmiöiden vuoksi. Tarkkuuden elementin avulla Helasvuo tuottaa nuottikuvaan ja esitykseen tarkkuuden, joka haihduttaa pois mahdollisuuden tehdä rytmiin agogisia ulottuvuuksia.

Helasvuo erottelee rytmin ja agogiikan erillisiksi ilmiöiksi myös kertoessaan Suvisoiton viimeisellä sivulla olevista liberamente-kuvioista, jotka koostuvat kolmesta kuudestoistaosanuotista joita seuraa kahdeksasosanuotti.

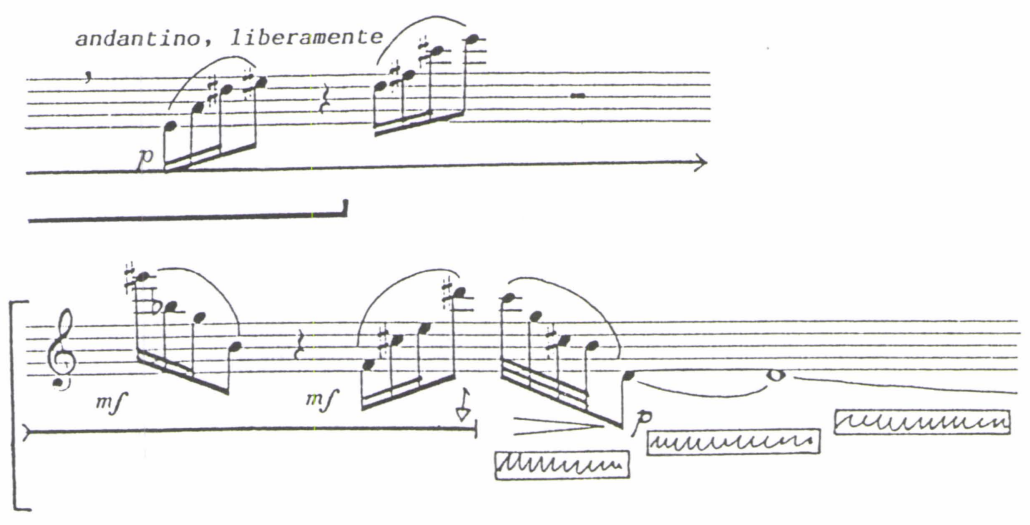

Kuva 2. Suvisoitto, 7/3 ja 4.

Hän sanoo yrittävänsä soittaa kuviot siten, että onnistuisi luomaan illuusion liberamentesta. Tämä koskee sekä kuvioiden ajoitusta suhteessa nauhaan että äänten kestoa suhteessa toisiinsa. Liberamente-illuusion luominen tapahtuu sil- 
lä tavalla, "ettei soita täsmälleen rytmissä". Liberamenten mukanaan tuoman vapauden vastakohta Helasvuon mielestä olisi esimerkiksi se, jos nuottikuvassa lukisi marciale militaristico, jolloin hän soittaisi kohdan aivan rytmissä. Kuvioille on hänen mielestään yhteistä ainoastaan se, että ne koostuvat kolmesta lyhyestä ja yhdestä pitkästä äänestä. Silloin kun tämä ehto täyttyy, niin soitetaan nuottikuvan määräämällä tavalla ja oikein. Kuvio on Helasvuon mielestä pieni moduli, "joka voi olla vaikka minkälainen", erilaisia mahdollisuuksia sen soittamiseksi on ääretön määrä. Erilaisesti soitetut kuviot ovat niinkuin saman puun lehtiä, joista jokainen on vähän erilainen verrattuna muihin. (IV: 6.) Liberamenten moduleissa vapaus ja tarkkuus kietoutuvat toisiinsa esityksen samassa hetkessä. Tarkkaa on ainoastaan rytmi, eli se, että kuviot muodostuvat kolmesta lyhyestä ja yhdestä pitkästä äänestä. Vapaus muodostuu äärettömästä mahdollisuuksien joukosta eli agogisista ratkaisuista ${ }^{11}$. Helasvuolle vapaus on näissä liberamentekuvioissa illusorista, hän yrittää ainoastaan luoda "illuusion", vaikutelman vapaudesta. Mihin esitys on sidottu huolimatta illusorisesta vapaudesta?

Liberamentekuviot on notatoitu palkein ja varsin varustetuilla nuoteilla. Tällainen nuottikirjoitustapa liitetään - kuten jo aikaisemmin tässä luvussa kirjoitin - pulssilliseen ja hierarkkiseen rytmikudokseen. Pulssi puolestaan käsitteellistetään tarkemmaksi ilmiöksi kuin "vapaa" ei-pulssillisuus. Helasvuo käsitteellistää kirjoitustavan vahvasti pulssilliseksi huolimatta liberamente-merkinnästä: tarkkuus on siitä huolimatta läsnä, että se yritetään peittää vapauden vaikutelmalla.

\section{Säveltaso-organisaatio}

Valtaosa säveltasoja koskevasta keskustelusta tässä aineistossa koskee mikrointervalleja, joita Suvisoitossa on melko paljon. Mikrointervallisuus tarkoittaa sitä, että oktaavi jakaantuu useampaan kuin kahteentoista osaan. Yleensä tämä jako tapahtuu neljäsosa-askelittain. Etenkin tuntitilanteissa käytetään paljon aikaa juuri mikrointervalleihin liittyvien ongelmien ratkomiseen.

\section{Mikrointervallit}

Seuraavassa tuntitilannekatkelmassa pohditaan Suvisoiton lento-jakson mikrointervallien toteutusta:

${ }^{11}$ Helasvuo puhuu tässä yhteydessä rytmistä muttei mainitse sanaa agogiikka. Nimitän vapauden elementin tuottamia ilmiöitä tässä agogiikaksi siksi, että Helasvuon kuvaama ilmiö rinnastuu Meriläisen Chopin-esimerkin rytmi/agogiikka käsitepariin. 
M. H.: Voit tehä myös näin [soittaa] mut tää on mahdotonta [soittaa] täs on kiva huuhkajamainen väri, huuhkajat syö heinäsirkkoja, syököhän ehkä ne on liian pieniä niille. Tossa tota [soittaa $\mathrm{d}^{1}$ alasp. glissando] siinä voi kääntää pelkästään. Matala g...

T. L.: Onks toi sit...

M. H.: No toi on se on vaikee tehdä matalaks [soittaa] vaikee saada hyvin tommonen matala g [soittaa] taikka sit yksinkertasesti [soittaa] sä voit käyttää kumpi on parempi [soittaa] tän ei pitäs kuulostaa terssiltä eikä kvartilta [soittaa] vaan siltä väliltä [soittaa] tää kuulostaa vähän sairaalta. (II: 5.)

Helasvuo tuottaa edellisessä sitaatissa puheessaan monia mahdollisia matalia g-ääniä. Muusikolle matala g ei siis ole yksi, vaan monta säveltasoltaan ja sointiväriltään erilaista ääntä. Mikrointervalleja voidaan tuottaa kahdella eri tavalla: joko sormitusten avulla, jolloin huiluun puhalletaan tavanomaisella tavalla tai sitten kääntämällä huilua tai muuttamalla huulten ja leuan avulla puhalluskulmaa muuttaen näin ilmavirran suuntaa, jolloin äänen korkeus muuttuu. Jokaiselle äänelle voidaan löytää monia eri sormituksia. Tulos riippuu soittajasta ja soittimesta. Epätavanomaisia sormituksia käytettäessä äänenväri muuttuu olennaisesti kun taas huilua käännettäessä ja ilmavirran suuntaa muutettaessa äänenväri pysyy vakiona.

Soittaessaan nuottikuvaa esitykseksi muusikon täytyy olla tietoinen siitä, milloin siirrytään säveltasosta toiseen, missä ovat kunkin äänen rajat. Tämän lisäksi hänen täytyy valita kunkin äänen monista mahdollisista varianteista intonaation eli äänen korkeuden ja mikrointervallien kohdalla myös äänen värin suhteen sopivin. Tässä ilmenee se erottelu, joka yleensä tehdään säveltasojen ja intonaation välillä: säveltasojen ajatellaan liittyvän siihen, mitä nuottikuvassa ilmoitetaan kun taas intonaatio käsitteellistetään liittyväksi soivaan ääneen, esitykseen.

Mikrointervallit käsitteellistetään yleensä ja myös tässä aineistossa viittaamalla oktaavin kahteentoista säveleen. Puhutaan esimerkiksi matalasta h:sta ja korkeasta gis:stä. Mikrointervallit määritellään asteikon kahdentoista sävelen kautta ja nämä kaksitoista säveltä puolestaan palautuvat pianon valkoisiin koskettimiin. Pianon mustat koskettimethan nimetään suhteessa valkoisiin koskettimiin. Sama ilmiö näkyy myös nuottikuvan tasolla: pianon valkoisista koskettimista poikkeavat sävelkorkeudet merkitään liittämällä etumerkit valkoisia koskettimia merkitsevien nuottien eteen.

Meriläinen kuvailee Suvisoiton lento-osan loppua seuraavasti:

- - siinähän tässä keskellä ollaan alueella jota ei oo olemassakaan sillä tavalla et jos ajatellaan näitä nuottiviivaston nuotteja niin tämmönen matala ee ja vähän korkea $\mathrm{f} j \mathrm{j}$ vähän korkea $\mathrm{d}$ siinä uidaan niinko täysin irrallaan siitä tästä perinteisestä rakenteesta ja nämä nuottiviivaston portaat ilmaisee että sävelellä on paikkansa niin nää täytyy merkitä siis sille tasolle mikä on lähinnä mutta siinä mennään täysin ulkopuolelle tän nuottiviivaston ilmaisemien sävelten ulkopuolelle ja siihen nyt on ihan tarkotus siin on tietty sävy tietty ominaisuus 
karakteri tulee siittä että irtaudutaan - - niistä sävelistä jotka on ne peruslähtökohdat ollaan ihan jossain muualla ja samanaikasesti tulee sitten tämä nauha tuottaa sitten tätä tämmöstä rytmistä materiaalia. (III: 11.)

Mitä Meriläinen tarkoittaa sillä, jota "ei ole olemassakaan", joka on "muualla" ja "nuottiviivaston ilmaisemien sävelten ulkopuolella"? Entä mitä toisaalta on olemassa, täällä ja nuottiviivastolla? Meriläinen kuvailee tätä samaa kohtaa myös sanomalla, että mennään alueelle jota ei olekaan ja joka irtautuu täysin perinteestä. Viimeinen rivi menee hänen kuvauksensa mukaan pitemmälle ja pitemmälle pois päättyen multifoniaan. (III: 11.)

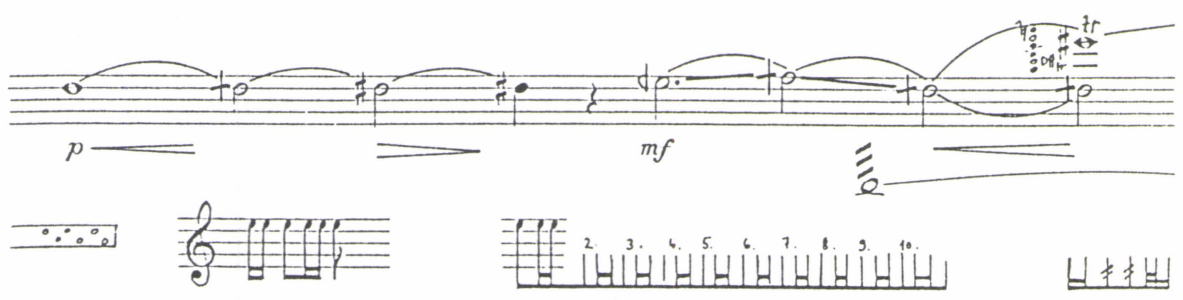

Kuva 3. Suvisoitto, 5/4.

Vastaus edellä esittämiini kysymyksiin löytyy siitä, että Meriläinen nimeää ei-mikrosävelaskeliset sävelet "selkeiksi säveltasoiksi", "normaalisäveliksi" ja "normaaleiksi sävelaskeleiksi" (III: 13-14). Tässä siis se, mitä "ei ole olemassakaan", tarkoittaa itse asiassa kaksitoistasävelisyydestä poikkeamista eli mikrointervalleja. Sävelavaruus jakaantuu vain kahteentoista osaan ja nuottiviivastossakaan ei ole omia paikkoja mikrointervalleille. Suvisoiton alun klastertapahtumassa on Meriläisen kuvailun mukaisesti tietyn sävelalueen kaikki peräkkäiset sävelet (III: 1) eli kaikki sävelet sellaisessa sävelavaruudessa, jossa oktaavi jakaantuu kahteentoista säveleeseen ja peräkkäiset sävelet ovat toisistaan puolisävelaskelen etäisyydellä. Myös intervallit määrätään kaksitoistasävelisesti eikä mikrointervalleja mukaan lukien (III: 1).

Helasvuo puolestaan luonnehtii mikrointervalleja "sairaiksi" (II: 5), "kokosävelaskelen välivaiheiksi" (II: 4) ja "epäpuhtaiksi" (II: 10). Mikrointervalleja täytyy kuunnella erityisen tarkasti siksi, että "ne on korvassa niin kauheesti noi puolsävelaskeleet (II: 6)". Mikrointervallin pitääkin kuulostaa joskus epäpuhtaalta ja esimerkiksi suorastaan liian korkealta (II: 10), jotta se kunnolla poikkeaisi kaksitoistasävelisestä standardista.

Suvisoiton lopussa on peräkkäin neljäsosasävelaskelen korkeat a, h ja c. Näitä seuraavat sävelet ovat ei-mikrointervallisia. Tässä siis luodaan vaikutelma neljäsosa-askeltranspositiosta. Helasvuo kuvaa tätä siirtymää palaamiseksi. Mikrointervallien pitäisi kuulostaa "puhtailta" sekä "diatonisesti oikeilta", ai- 
van kuin ne olisivat "diatonista skaalaa". Tällöin kuulija huomaa "putoamisen" vasta siirtymän tapahtuessa". (II: 7, 14-15.)



Kuva 4. Suvisoitto, 7/5.

Mikrointervallien referentti on siis tässäkin tapauksessa kaksitoistasävelinen, ja kun siirtymä tapahtuu, pudotaan kaksitoistasävelisestä järjestelmästä toiseen. Mikrointervalleilla on luotu vaikutelma diatonisesta asteikosta, joka romuttuu siirryttäessä ei-mikrointervallisiin ääniin. Nämä kaksi säveljärjestelmää eivät integroidu toistensa osiksi vaan ne täytyy käsitteellistää erilleen toisistaan. Tässä esimerkissä tapahtuu kuitenkin näiden ilmiöiden jännittävä sekoittuminen toisiinsa: mikrointervallien ajatellaan tuottavan kaksitoistasävelistä tai jopa diatonista todellisuutta yksin esiintyessään mutta niiden esiintyessä yhdessä ei-mikrointervallisten sävelien kanssa toinen on aina kaksitoistasävelisen järjestelmän referentti.

Sävelavaruus tuotetaan siis mikrointervallien käytöstä huolimatta yhä edelleen hyvin kaksitoistasäveliseksi ja tästä systeemistä mennään ulos silloin kun soitetaan mikrointervalleja. Miten mikrointervallit voivat ylipäätään olla $\mathrm{Su}$ visoitossa mahdollisia ja perusteltuja?

Meriläinen lieventää mikrointervallien käytöstä syntyvää ristiriitaa asettamalla mikrointervallit huilussa olemassaoleviksi asioiksi: mikrointervallit ovat puhallinsoittimissa ja huilussa "luonnostaan käsillä". Yläsävelsarjasta hän sanoo, että "mitä pitemmälle mennään niin sitä enemmän siellä tulee näitä mikrointervalleja". (III: 10-11.) Different fingerings -kohdissa mikrointervallit tapahtuvat "väistämättä" ja "luonnostaan" (III: 1-2). Näissä lausumissa toistuu niiden passiivinen luonne: mikrointervallien sijoittaminen säveltäjän ja muusikon ulkopuolelle, luonnollisuuteen ja soittimeen ${ }^{12}$.

Ehdottomasti tärkeimmän mikrointervallien perusteen löytymiseksi täytyy siirtyä pois säveltaso-organisaatiosta, toiseen parametriin. Meriläinen ja Helasvuo pitävät molemmat mikrointervallien ensisijaisena toteutuskeinona sormitusta eikä puhalluskulman muuttamista (II: 4-5, II: 11-12, III: 12). Meriläisen

12 Aineistossa on myös yksi epäpassiivinen luonnehdinta mikrointervalleista: Meriläinen sanoo, että "- - ne on huilulla hyvin helposti aikaan saatavissa noi [mikrointervallit] (III: 14)." 
mielestä mikrointervallit olivat "vaimeita" esityksessä, jossa ne tehtiin kääntämällä huilua (III: 12). Sormituksia käyttämällä mikrointervallien sointiväri on erilainen kuin oktaavin kahdentoista sävelen sointiväri sellaisina kuin ne "tavallisesti" soitetaan. Mikrointervallien käytön perusteeksi ei näin ollen riitä sävelavaruuden laajeneminen vaan ensisijainen syy on sointivärin vaihtuminen. Kaksitoistasävelisyydestä ei siis poiketa ensisijaisesti ja paradoksisen yllätyksellisesti säveltasojen vaan ennen kaikkea sointivärin vuoksi.

\section{Säveltasojen keskeinen asema}

Säveltasojen ajatellaan olevan määritellyn joka hetkenä Suvisoiton nuottikuvassa. Sävelkorkeuden piirissä liikkumavapaus on tästä syystä erittäin pieni; Meriläinen ei mainitse tästä mitään. Helasvuo puhuu suoranaisesti ${ }^{13}$ sävelkorkeutta koskevasta vapaudesta kaksi kertaa koko aineistossa: Suvisoiton viidennen sivun toisella rivillä voi "leikkiä vähän tonaliteetilla" niin, että huilu ja nauha muodostavat toisinaan puhtaita intervalleja. Tämä on Helasvuon mielestä tulkinnallinen, jännitettä luova asia. (IV: 6.) Intonaation kanssa voi Helasvuon mukaan "pelata aika paljon". Tässä kohtaamme taas säveltasojen ja toisaalta intonaation välisen eron. Tarkkuuden elementti tuottaa säveltason erittäin tarkasti tiettyyn rajaan asti, jonka sisällä voidaan vapaasti valita erilaisia sävelkorkeuksia intonaation nimissä. Nuottikuvassa ilmoitetuiksi ajatellut säveltasojen sisään mahtuu monenlaisia intonaatioita. Pääpiirteissään sävelkorkeudet kuuluvat tarkkuuden ja intonaatio vapauden elementin piiriin silloin kun puhutaan siitä, miten tarkasti nuottikuvan tai säveltäjän ajatellaan määrittävän sävelkorkeuden ${ }^{14}$.

Muusikko voi siis vaikuttaa sävelten intonaatioon, mutta säveltasoja koskevasta vapaudesta hän ei puhu mitään. Säveltasojen määrittely näyttää kuuluvan ehdottomasti säveltäjän tehtäviin: Meriläisen mukaan "äärimmäisin" improvisaation muoto, jota hän voi kuvitella käyttävänsä, on se, että hän antaa soittimille tai soittajille improvisaatiojaksossa käytettävät sävelet ja ehkä myös rytmimotiivit (I: 8). Säveltasojen määritteleminen on siis säveltämisen ja sävellyksen tekemisen ehdoton edellytys.

${ }^{13}$ Mikrointervallit kuuluvat tietysti osittain sävelkorkeuden piiriin ja niihin liittyy melko paljon vapautta: sävelkorkeutta koskeva aineisto koskee muusikon osalta valtaosaltaan juuri mikrointervallien tuottamiseen liittyvän valinnanvapauden ongelmia. Silti edellä olevan perusteella on selvää, että mikrointervallit ovat tässä aineistossa ensisijaisesti sointivärillisiä ilmiöitä. Mikrointervalleissa ei kyse ole kuitenkaan sävelkorkeuteen liittyvästä vapaudesta vaan nuottikuvan ajatellaan tuottavan kohtuullisen yksiselitteisesti sen frekvenssihaarukan, jonka väliin äänen tulee sijoittua.

14 Täytyy kuitenkin muistaa, että muissa konteksteissa tilanne saattaa olla toinen: esimerkiksi tietyn äänen tietynlaisen intonaation tuottaminen saattaa jossakin tilanteessa olla erittäin tarkkaa. 
Säveltäjän määrittelemiin teoksen ilmiöihin eivät kuulu ainoastaan sävelkorkeudet vaan myös niiden suhteet toisiinsa. Säveltäjälle sävelavaruus jakautuu nuottikuvassa ilmoitetuiksi ajateltuihin osiin, sävelkorkeuksiin. Tämän lisäksi hän puhuu säveltaso-organisaatiosta eli siitä, miten nämä nuottikuvalliset kategoriat suhteutuvat toisiinsa vertikaalisesti ja horisontaalisesti. Säveltäjäpuhuu klastertapahtumista, sävelkentistä, intervalliulottuvuuksista ja tonaalisesta väljyydestä. Muusikko ei puhu mitään tämänkaltaisesta äänten suhteesta toisiinsa.

\section{Meriläinen, Helasvuo ja Suvisoitto}

Miten tarkkuuden ja vapauden elementit liittyvät luovan ja esittävän säveltaiteen diskursseihin? Pyrin artikkelin lopuksi rakentamaan sillan näiden käsiteparien välille edellä esitetyn analyysin perusteella. Parametrien käsittelyjärjestys tässä kirjoituksessa ei ole sattumanvarainen, vaan niillä on tutkimuksessa käytetyn aineiston perusteella tarkkuuden ja vapauden elementtien tuottama järjestys. Edellä esitetyn analyysin perusteella parametrit voidaan esittää seuraavassa järjestyksessä:

vapaus

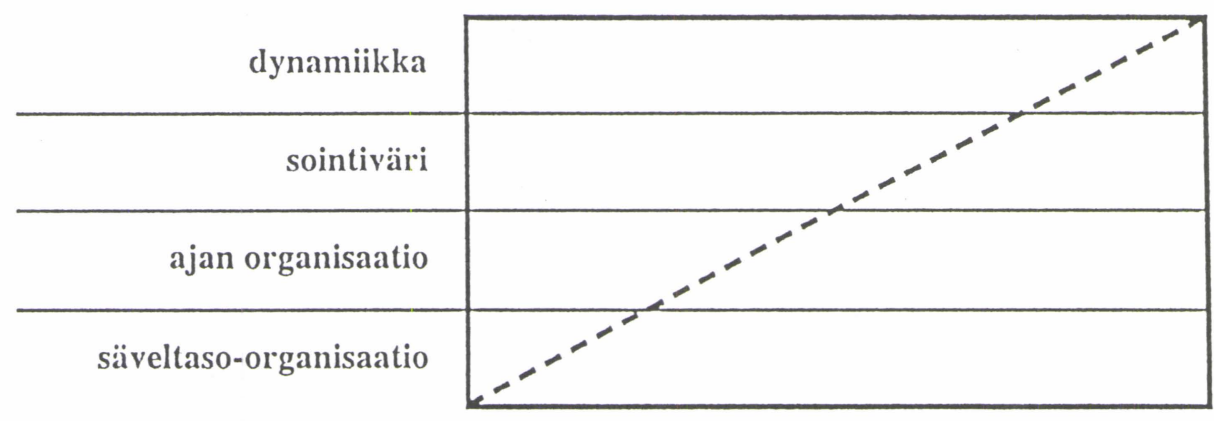

tarkkuus

Kuva 5. Parametrit suhteessa tarkkuuden ja vapauden elementteihin.

Tässä tarkkuus on suurimmillaan alhaalla ja vähenee ylöspäin mentäessä. Vapaus on suurimmillaan ylhäällä ja pienenee alaspäin mentäessä. Kaaviota halkaiseva poikkiviiva kuvaa sitä, että dynamiikkaan voi sisältyä myös tarkkoja ulottuvuuksia ja säveltaso-organisaatioon voi sisältyä vapaita ulottuvuuksia esimerkiksi intonaation muodossa. Koska tarkkuuden elementin avulla aineistossa selitettiin Suvisoiton nuottikuvallisia ulottuvuuksia ja vapauden elementin avulla esityksellisiä ulottuvuuksia, edellä oleva kaavio voidaan piirtää myös seuraavaan muotoon: 
esitys



nuottikuva

Kuva 6. Parametrit suhteessa nuottikuvaan ja esitykseen.

Sävelkorkeuden piirissä liikkumavapaus on erittäin pieni ja jopa intonaationkin kohdalla vapaus on melko pientä. Säveltaso-organisaatio ja ajan organisaatio ajatellaan sävelkorkeuksien ja rytmin osalta joka hetkenä määritellyiksi nuottikuvassa toisin kuin dynamiikka ja sointiväri, jotka käsitteellistettiin enemmän esityksellisiksi parametreiksi. Sellaisia merkintöjä, joiden ajatellaan merkitsevän dynamiikkaa ja sointiväriä, tulkitaan nuottikuvassa olevan vain silloin tällöin. Nuottikuvan tekeminen on säveltäjän tehtävä ja esityksen tekeminen on muusikon tehtävä. Kaavio voidaan siis piirtää myös tähän muotoon:

muusikko

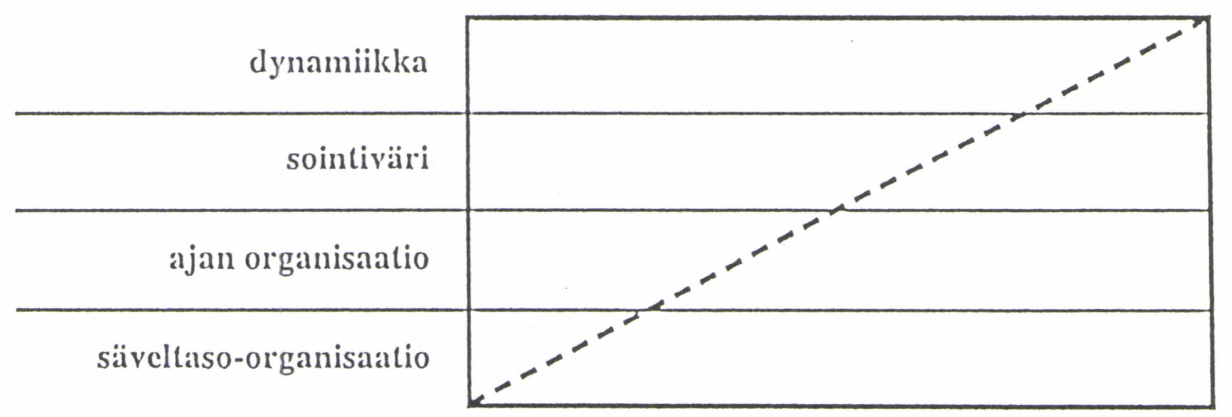

sävellïjä

Kuva 7. Säveltäjän ja muusikon tehtävät Suvisoiton parametrien määrittelemisessä.

Tarkkuuden ja vapauden elementit ovat siis sidoksissa luovan ja esittävän säveltaiteen diskursseihin siten, että ne määrittelevät säveltäjän ja muusikon 
työnjaon musiikkiteoksen määrittelemisessä. Ne parametrit, jotka tässä aineistossa tuotettiin tarkkuuden elementin avulla, muodostuvat sellaisista Suvisoiton määrittelyistä, joille säveltäjän ajatellaan antavan merkityksen. Tarkkuuden toteuttamisesta vallitsee useimmiten säveltäjän ja muusikon välillä yhteisymmärrys; muusikko yrittää parhaansa mukaan toteuttaa esityksessä niitä asioita, jotka hänen mielestään kuuluvat säveltäjän tarkan määrittelyn piiriin. Ne parametrit, jotka tässä aineistossa tuotettiin vapauden elementin avulla, muodostuvat sellaisista Suvisoiton määrittelyistä, joille muusikon ajatellaan antavan merkityksen. Tästäkin työnjaosta vallitsee yleensä yhteisymmärrys siten, että säveltäjä ei edes pyri tarkkaan teoksen määrittelyyn niiltä osin kuin hän ajattelee sen muusikon tehtäväksi. Tarkkuuden ja vapauden raja musiikkiteoksen määrittelyssä on siis monimutkaisuudessaan erittäin hienovaraisesti jaettu. Tämän artikkelin tarkastelun ulkopuolelle jää sen historiallisen prosessin tarkasteleminen, jonka tulos edellä mainittu yksimielisyys on.

Miten voin tämän aineiston perusteella purkaa luovan ja esittävän säveltaiteen dikotomiaa? Tätä tarkoitusta varten täytyy tarkastella sitä, millaisia mahdollisuuksia Meriläisellä ja Helasvuolla on antaa Suvisoitolle merkityksiä. Ensiksi käsittelen tätä asiaa henkilöityneen tekijäkäsityksen kannalta. Jos ajatellaan, että luovuus musiikkiteoksen määrittelyssä tarkoittaa sanakirjamäärityk$\operatorname{sen}^{15}$ mukaisesti "tuottamista" ja esittävyys "tulkintaa", niin Meriläisen ja Helasvuon suhde näihin ulottuvuuksiin voidaan määritellä tällä tavalla:

Säveltäjän esittävyys



Kuva 8. Parametrit luovan ja esittävän säveltaiteen diskursseissa. (Jatkuu.)

${ }^{15} \mathrm{Kts}$. tämän artikkelin alussa esitetyt sanakirjamääritelmät 
Muusikon luovuus

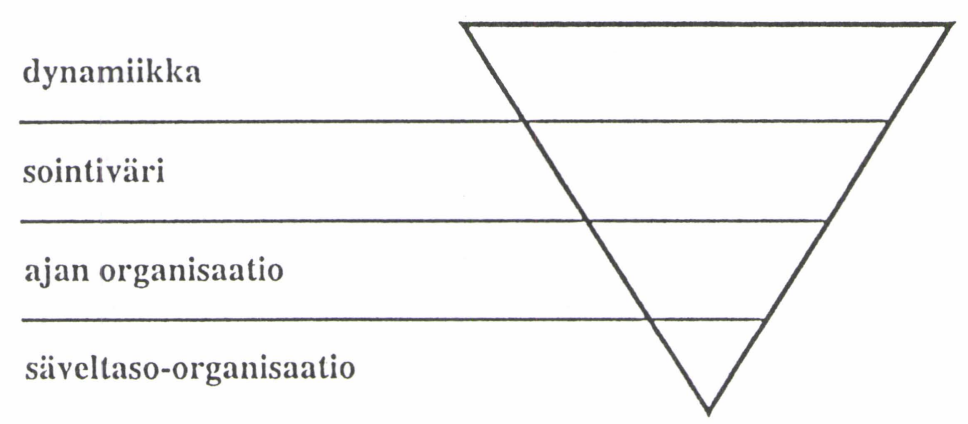

Säveltäjän luovuus

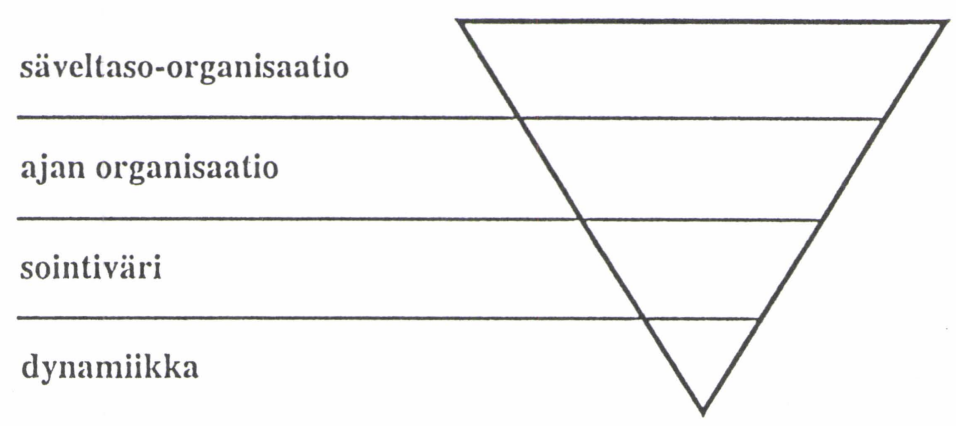

Muusikon esittävyys

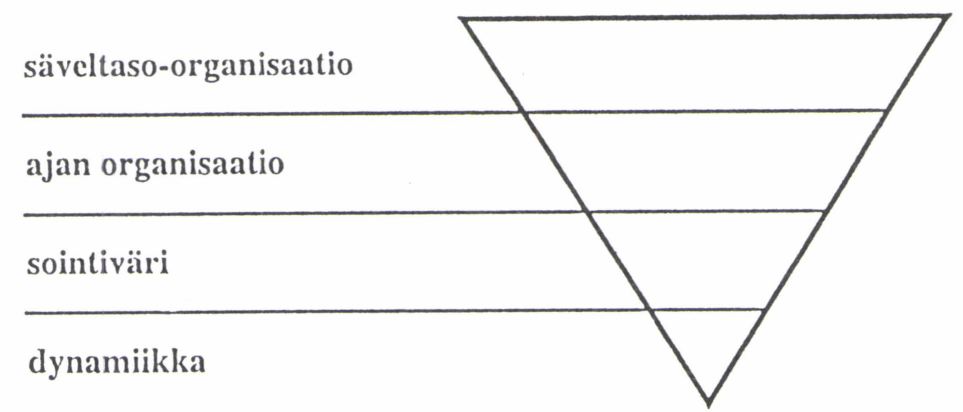

Kuva 8. (Jatkoa.) 
Nämä kaaviot kuvaavat sitä, että Meriläisen luovuus on suurimmillaan säveltasoorganisaatio suhteen ja pienimmillään koskien Suvisoiton dynaamisia ulottuvuuksia. Säveltäjän esittävyys on suurimmillaan dynaamisten ulottuvuuksien ja pienimmillään säveltaso-organisaation suhteen. Helasvuon luovuus on suurimmillaan dynamiikan suhteen ja pienimmillään koskien säveltaso-organisaatiota. Muusikon esittävyys on suurimmillaan säveltaso-organisaation ja pienimmillään dynamiikan suhteen. Luovuus voidaan siis ajatella merkityksenannon mahdollisuutena ja esittävyys suostumisena jonkun muun merkityksenantoon. Luovan ja esittävän säveltaiteen dikotomia hajoaa tämän aineiston perusteella siihen, että molemmat - Meriläinen ja Helasvuo - tässä mielessä sekä luovat että esittävät. Sekä muusikon että säveltäjän tekemiseen liittyy esittäviä ulottuvuuksia, sillä molemmat puhuvat sijoittumisestaan erilaisiin tulkintatraditioihin. Meriläinen ja Helasvuo ovat molemmat musiikkiteoksen tekijöitä siten, että antavat sille merkityksiä. Kyse ei ole siitä, että muusikko toistaisi säveltäjän merkitykset, jota esittävä toiminta sanakirjamäärityksen mukaisesti edellyttäisi. Helasvuo antaa Suvisoitolle merkityksiä siinä missä Meriläinenkin ja on siis tässä mielessä Suvisoiton tekijä. Muusikon vastuulla on enemmän teoksen määritteleminen dynamiikan ja sointivärin osalta kun taas säveltäjän tehtävät painottuvat teoksen määrittelemiseen säveltaso-organisaation ja ajan organisaation osalta. Teoksen määrittelemisen mahdollisuuksien jakaantumisesta huolimatta on kuitenkin selvää, että säveltäjällä on välttämättä enemmän valtaa teoksen määrittelemisessä länsimaisessa taidemusiikkikulttuurissa vallitsevan parametrien arvohierarkian vuoksi.

Ei-henkilöityneen tekijyyskäsityksen ${ }^{16}$ mukaisesti voidaan sanoa, että luovan ja esittävän säveltaiteen diskurssit määrittelevät Meriläisen ja Helasvuon välisen valtasuhteen musiikkiteoksen merkityksenannon prosessissa. Myös musiikkiteos - tässä tapauksessa Suvisoitto - määritellään säveltäjän ja muusikon kahdensadan vuoden aikana muodostuneen tehtävänjaon perusteella.

\section{Lähteet}

\section{Kirjallisuus}

Barthes, Roland 1993a. Tekijän kuolema.Teoksessa Tekijän kuolema. Tekstin syntymä. Toimittanut Lea Rojola. Suomentaneet Lea Rojola ja Pirjo Thorell. Tampere: Vastapaino. S. 111-117.

Barthes, Roland 1993b. Teoksesta tekstiin. Teoksessa Tekijän kuolema. Tekstin syntymä. Toimittanut Lea Rojola. Suomentaneet Lea Rojola ja Pirjo Thorell. Tampere: Vastapaino. S. 159-168.

16 Ei-henkilöityneestä tekijyyskäsityksestä kts. Barthes 1993a; Barthes 1993b ja Foucault 1986. Tekijän eliminoinnin ongelmista suhteessa feministiseen musiikintutkimukseen kts. Citron 1993, 118. 
Citron, Marcia J. 1993. Gender and the Musical Canon. Cambridge: Cambridge University Press.

Foucault, Michel 1986. What Is An Author? Teoksessa The Foucault Reader. Ed. by Paul Rabinow. Harmondsworth: Penguin Books. S. 101-120.

Foucault, Michel 1991. The Archaelogy of Knowledge. Translated from French by A. M. Sheridan Smith. London: Tavistock Publications.

Goodman, Nelson 1981. Languages of Art. An Approach to a Theory of Symbols. Second Edition. Oxford: Oxford University Press.

Grossberg, Lawrence 1995. Mielihyvän kytkennät. Risteilyjä populaarikulttuurissa. Suomentaneet ja toimittaneet Juha Koivisto, Mikko Lehtonen, Ensio Puoskari ja Timo Uusitupa. Tampere: Vastapaino.

Jokinen, Arja ja Juhila, Kirsi 1991. Diskursseja rakentamassa. Näkökulmia sosiaalisten käytäntöjen tutkimiseen. Tampereen yliopisto, Sosiaalipolitiikan laitos. Tutkimuksia, Sarja A, nro 2. Tampere: Tampereen yliopisto.

Jokinen, Arja, Juhila, Kirsi ja Suoninen, Eero 1993. Diskurssianalyysin aakkoset. Tampere: Vastapaino.

Lehtonen, Mikko 1994. Kyklooppi ja kojootti. Subjekti 1600-1900-lukujen kulttuuri-ja kirjallisuusteoriassa. Tampere: Vastapaino.

Leppänen, Taru 1996. Teos ja tekijyys. Säveltäjä ja muusikko musiikkiteoksen tuottajina. Turun yliopiston taiteiden tutkimuksen laitos. Musiikkitieteen lisensiaatintutkimus. (Moniste.)

Levinson, Jerrold 1990. Music, Art, \& Metaphysics. Essays in Philosophical Aesthetics. New York: Cornell University Press.

Wolterstorff, Nicholas 1980. Works and Worlds of Art. Oxford: Clarendon Press.

Haastattelu- ja tuntiaineisto (Taru Leppäsen hallussa)

I. Usko Meriläisen haastattelu 29.4.1994

II. Mikael Helasvuon oppitunti 24.5.1994

III. Usko Meriläisen haastattelu 9.11.1994

IV. Mikael Helasvuon haastattelu 12.11.1994

Mikael Helasvuon oppitunti 6.6.1994

Nuotti

Meriläinen, Usko 1979. Suvisoitto huilulle ja heinäsirkoille. Edition Pan.

Äänite

Summer Sounds for Flute and Grasshoppers (1979) (fl \& tape) ODE-742-2 Mikael Helasvuo, huilu. 